University of Wollongong

Research Online

Faculty of Engineering and Information

Faculty of Engineering and Information

Sciences - Papers: Part A

Sciences

$1-1-2013$

Radial consolidation model incorporating the effects of vacuum preloading and non-Darcian flow

Kourosh Kianfar

University of Wollongong, kourosh@uow.edu.au

Buddhima Indraratna

University of Wollongong, indra@uow.edu.au

Cholachat Rujikiatkamjorn

University of Wollongong, cholacha@uow.edu.au

Follow this and additional works at: https://ro.uow.edu.au/eispapers

Part of the Engineering Commons, and the Science and Technology Studies Commons

Research Online is the open access institutional repository for the University of Wollongong. For further information contact the UOW Library: research-pubs@uow.edu.au 


\title{
Radial consolidation model incorporating the effects of vacuum preloading and non-Darcian flow
}

\begin{abstract}
A modified $150 \mathrm{~mm}$ Rowe cell equipped with pore water pressure measurement was used to capture the flow relationship during vacuum-assisted radial consolidation. Based on the measured data, a radial consolidation model incorporating the effects of vacuum preloading is proposed, based on a non-linear relationship between the flow velocity and hydraulic gradient. The predictions of the proposed consolidation model are then compared with the predictions based on Hansbo's Darcian and non- Darcian models. The agreement between the proposed model and the measured data is shown, and the advantages of the proposed model compared with the existing models are discussed. An embankment case history taken from the reclamation project at the Port of Brisbane, Australia, was analysed, based on the current solution, and compared with the field measurements.
\end{abstract}

\section{Keywords}

non, preloading, darcian, vacuum, flow, effects, incorporating, model, consolidation, radial

Disciplines

Engineering | Science and Technology Studies

\section{Publication Details}

Kianfar, K., Indraratna, B. \& Rujikiatkamjorn, C. (2013). Radial consolidation model incorporating the effects of vacuum preloading and non-Darcian flow. Geotechnique: international journal of soil mechanics, 63 (12), 1060-1073. 


\title{
Radial consolidation model incorporating the effects of vacuum preloading and non-Darcian flow
}

\author{
K. KIANFAR* ${ }^{*}$ B. INDRARATNA $\uparrow$ and C. RUJIKIATKAMJORN†
}

\begin{abstract}
A modified $150 \mathrm{~mm}$ Rowe cell equipped with pore water pressure measurement was used to capture the flow relationship during vacuum-assisted radial consolidation. Based on the measured data, a radial consolidation model incorporating the effects of vacuum preloading is proposed, based on a non-linear relationship between the flow velocity and hydraulic gradient. The predictions of the proposed consolidation model are then compared with the predictions based on Hansbo's Darcian and nonDarcian models. The agreement between the proposed model and the measured data is shown, and the advantages of the proposed model compared with the existing models are discussed. An embankment case history taken from the reclamation project at the Port of Brisbane, Australia, was analysed, based on the current solution, and compared with the field measurements.
\end{abstract}

KEYWORDS: consolidation; ground improvement; laboratory tests; seepage

\section{INTRODUCTION}

Terzaghi (1925) developed the conventional theory of onedimensional consolidation, based on the assumptions that soil volume change is small compared with its initial volume (small-strain theory), and the coefficient of permeability, compressibility and external load are constant. Schiffman (1958) developed the solution further by incorporating the influence of permeability variation and time dependence of the loading during consolidation. Barron (1948) developed analytical solutions for radial consolidation for the cases of free strain and equal axial strain, which were further modified by various researchers, including Kjellman (1952), Yoshikuni \& Nakanodo (1974), Onoue (1988), and Zeng \& Xie (1989). Hansbo (1960) developed a radial consolidation model based on a non-linear flow relationship. The effects of a varying coefficient of horizontal permeability and coefficient of compressibility during radial consolidation of clay were incorporated in a Darcian-based analytical model by Indraratna et al. (2005a). Sathananthan \& Indraratna (2006) developed a plane-strain lateral consolidation model that is applicable to both Darcian and non-Darcian flows. The results from the proposed model provide a more realistic lateral distribution of the excess pore water pressure than those predicted under Darcian flow conditions. Most of the existing analytical models for radial consolidation are based on Darcy's law for permeability, which might not apply for the consolidation of fine-grained soils under low hydraulic gradients (Hansbo, 1960, 2001). All the existing Darcianbased and non-Darcian-based models rely on accurate determination of the coefficient of permeability and coefficient of consolidation. Different techniques for measurement of the coefficient of permeability result in different values (e.g. Olsen, 1965, 1966). The value of the coefficient of consoli-

Manuscript received 27 October 2012; revised manuscript accepted 22 March 2013. Published online ahead of print 14 May 2013.

Discussion on this paper closes on 1 February 2014, for further details see p. ii.

* Centre for Geomechanics and Railway Engineering, School of Civil Engineering, University of Wollongong, Australia; Coffey Geotechnics, Australia.

$\uparrow$ Centre for Geomechanics and Railway Engineering, School of Civil Engineering, University of Wollongong, Australia. dation also depends on the calculation method adopted (e.g. Vinod et al., 2010).

Both linear and non-linear relationships between flow velocity and hydraulic gradient have been observed in finegrained clays (e.g. Hansbo, 1960; Olsen, 1966). In general, there is no unique relationship between the flow rate and hydraulic gradient, owing to factors such as the applied hydraulic gradient and seepage-induced consolidation (Olsen, 1966). During radial consolidation, phenomena such as the migration of grains, seepage-induced consolidation, clogging of the flow channels, reorientation of the grains, change in the hydraulic gradient, possible change in temperature, and change in the average viscosity of pore water due to the change in pores, might occur simultaneously. This might produce a relationship between the flow rate and hydraulic gradient during radial consolidation that is completely different from those that were determined based on conventional permeability or oedometer tests. Therefore, to capture more realistic flow characteristics, the actual flow relationship must be obtained during consolidation.

\section{IMPLICATIONS OF NON-DARCIAN FLOW}

It has been shown experimentally that Darcy's law for permeability is not always valid for a low-porosity soil (Winterkorn, 1954; Schmid, 1957), or for seepage flow under low hydraulic gradients (Kezdi, 1958). Hansbo (1960) also showed that the relationship between flow velocity and hydraulic gradient of normally consolidated plastic clays under low hydraulic gradients deviates from Darcy's law. Based on laboratory observations, a relationship between the flow velocity and hydraulic gradient was proposed to capture a nonlinear correlation under low hydraulic gradient, followed by a linear relationship at a higher hydraulic gradient (Fig. 1). The relationships between the flow velocity and hydraulic gradient are expressed by (Hansbo, 1960)

$$
\begin{aligned}
& v=\kappa i^{m} \text { when } i \leqslant i_{1} \\
& v=k\left(i-i_{0}\right) \text { when } i \geqslant i_{1} \\
& i_{0}=\frac{i_{1}(m-1)}{m}
\end{aligned}
$$

where $v$ is the flow velocity; $i$ is the hydraulic gradient; $m$ is a constant that depends on the soil type, void ratio and 


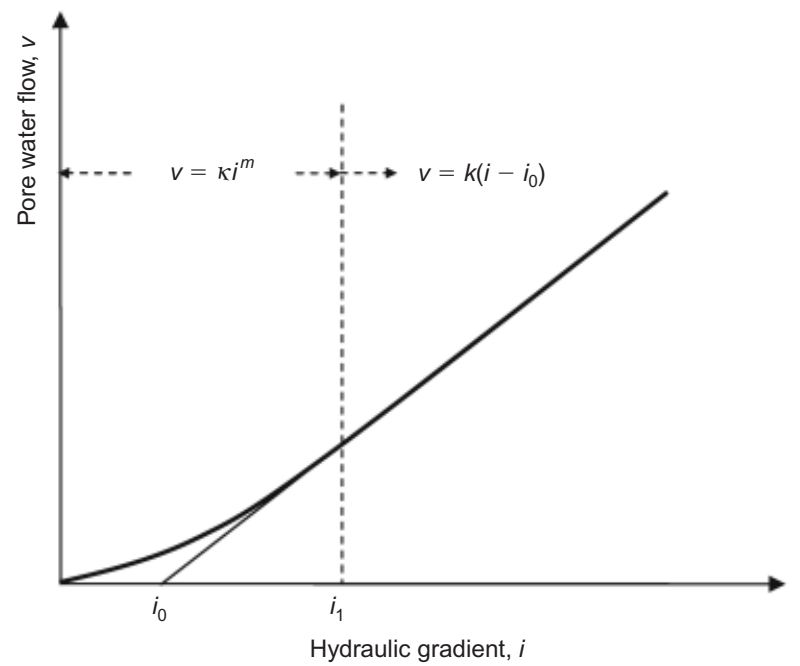

Fig. 1. Pore water flow against hydraulic gradient in normally consolidated clay subjected to small hydraulic gradient (after Hansbo, 1960)

temperature; $\kappa$ is the coefficient of permeability based on non-linear flow; and $k$ is the coefficient of permeability based on linear flow for a given soil.

The relationship between $\kappa$ and $k$ is given by

$$
k=m \kappa i_{1}^{m-1}
$$

It is shown that the best agreement between the analytical and field data could be obtained if $m$ equals 1.5 (Hansbo, 1960, 2001).

According to Hansbo (1960), $i_{1}$ is the hydraulic gradient needed to overcome the maximum binding energy of mobile pore water, and it can vary between 4 and 10; however, Dubin \& Moulin (1986) reported that $i_{1}$ values can be in the range $8-35$. Based on the above equations, Hansbo (1960) developed a radial consolidation model that captured nonDarcian flow, and explained that the hydraulic gradient in the field is much lower than the hydraulic gradient in a small-scale laboratory test on radial consolidation. The relationship between the field and laboratory conditions based on hydraulic gradient can then be determined by

$$
\left(\frac{\partial u}{\partial r}\right)_{1}=\frac{D_{\mathrm{f}}}{D_{\mathrm{l}}}\left(\frac{\partial u}{\partial r}\right)_{\mathrm{f}}
$$

where $u$ is the excess pore water pressure; $D$ is the influence zone diameter; $r$ is the radius measured from the centre of the drain; and subscripts $\mathrm{f}$ and 1 represent field and laboratory conditions respectively.

Equation (5) shows that the pore water pressure gradients that occur in the small-scale laboratory tests are much higher than those in the field. Hansbo (1960) emphasised that an inaccurate prediction can result from this inconsistency, if the proposed limit $\left(i_{1}\right)$ between the non-linear and linear relationships of the pore water flow and hydraulic gradient (Fig. 1) exceeds the simulated hydraulic gradient in the laboratory tests but not in the field. Therefore this non-linear model is only applicable to field conditions.

Several previous test results for saturated clays have also shown a deviation from Darcy's law (e.g. Lutz \& Kemper, 1959; Miller \& Low, 1963; Zou, 1996). However, Olsen $(1965,1966)$ showed that these deviations can be attributed to possible errors in the conventional measurement techniques for obtaining the permeability of fine-grained soils. The errors can be due to atmospheric contamination, the long time intervals needed to obtain a measurable flow rate, the large hydraulic gradients used in the laboratory tests, or the partially confined or unconfined clay fractions within the rigid skeletons of coarser particles in the laboratory tests. Olsen (1966) stated that resolving these errors can result in relationships between the flow rate and hydraulic gradient that imply validation of Darcy's law. Probable exceptions can be observed in extremely fine-grained clays, where large hydraulic gradients exist in shallow unconfined sediments (Olsen, 1966). Mitchell \& Younger (1967) also emphasised that the hydraulic gradient in the laboratory during consolidation tests was much larger than in field conditions. However, in contrast to Olsen's (1966) opinion, they argued that at low hydraulic gradients the deviations from Darcy's law are very significant, and any analysis of field consolidation based on the laboratory results requires scrutiny. Pane et al. (1983) argued that very small hydraulic gradient conditions are required to measure the permeability of soft clays reliably, whereas a higher applied hydraulic gradient (i.e. $>1.4$ ) can induce some consolidation during a permeability test. Several studies have reported that, possibly attributed to this, the hydraulic conductivity decreases as the hydraulic gradient increases (e.g. Mitchell \& Younger, 1967; Gairon \& Swartzendruber, 1975; Foreman \& Daniel, 1984; Acar et al., 1985; Edil \& Erickson, 1985; Carpenter \& Stephenson, 1986; Kodikara \& Rahman, 2002).

\section{LABORATORY DETERMINATION OF RADIAL FLOW CHARACTERISTICS DURING CONSOLIDATION TESTS}

A modified $150 \mathrm{~mm}$ Rowe cell (Fig. 2(a)) was utilised to capture the flow relationship during radial consolidation tests. Fig. 2(b) shows a schematic illustration of the Rowe cell and the locations of the pore water pressure measurements (A, B, C and D). Regions A, B, C and D measure pore pressure at $0-7.5 \mathrm{~mm}, 15.75-24.25 \mathrm{~mm}, 35.75-$ $44.25 \mathrm{~mm}$ and $55 \cdot 75-64.25 \mathrm{~mm}$ from the centreline. Kaolin was used as the soil, and its properties are summarised in Table 1. Three tests were conducted with different combinations of surcharge (SP) and vacuum (VP) pressure to capture the flow relationship, and the details are summarised in Table 2 . The clay slurry was prepared by mixing kaolin with de-aired water to obtain a water content of at least 1.5 times its liquid limit, and was then kept in a sealed container for a few days before transferring it to the cell. To avoid the development of preferential flow paths between soil and baseplate, a thin layer of grease was applied to the baseplate of the cell, except for the pore water measurement locations, to act as an impermeable boundary. To ensure that the sample was fully saturated, Skempton's $B$ parameter was checked to achieve at least $B=0.99$, and then it was preconsolidated under $30 \mathrm{kPa}$. A $14.5 \mathrm{~mm}$ diameter sand drain was installed in the centre of the sample by way of a pre-bored hole to minimise the smear effect. The air entry value is approximately $1-2 \mathrm{kPa}$, using the estimation method proposed by Fredlund et al. (2002). A surcharge pressure of $30 \mathrm{kPa}$ was re-applied until the strain rate was less than $0 \cdot 015 \% / \mathrm{h}$. An additional vertical load was then imposed in tandem with the vacuum pressure applied to the central drain to mimic the membraneless technique in the field. The excess pore water pressure was monitored during the tests, and measured at four different locations (Fig. 2(b)).

The calculation of the hydraulic gradient in the radial direction was based on the measurements at two regions (i.e. regions $\mathrm{B}$ and $\mathrm{C}$ in Fig. 2(b)). The middle locations were chosen to calculate the hydraulic gradient, because they were sufficiently far enough from both boundaries (sand drain and the cell wall) to minimise any boundary effects. Fig. 3 represents the distribution of excess pore water pressure with 


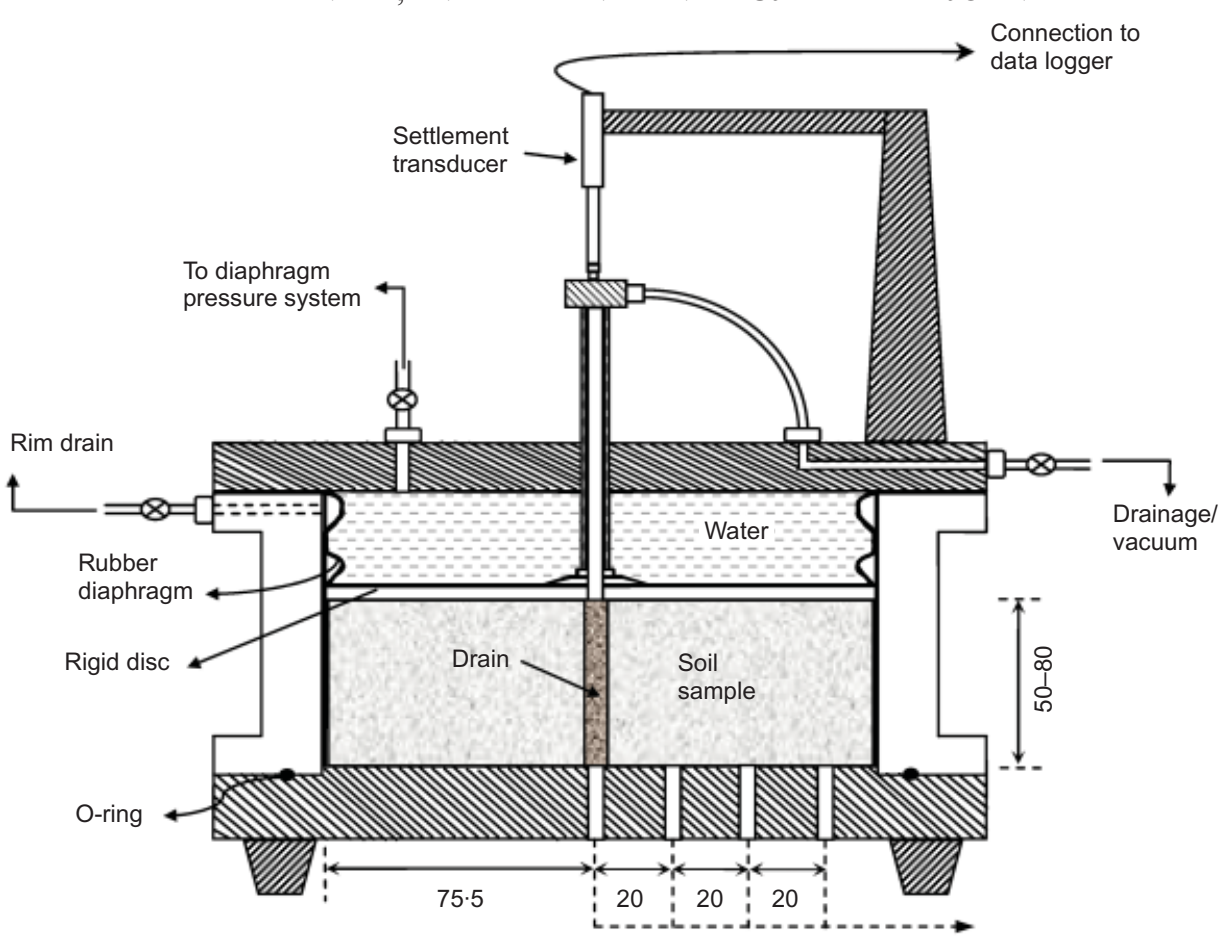

(a)

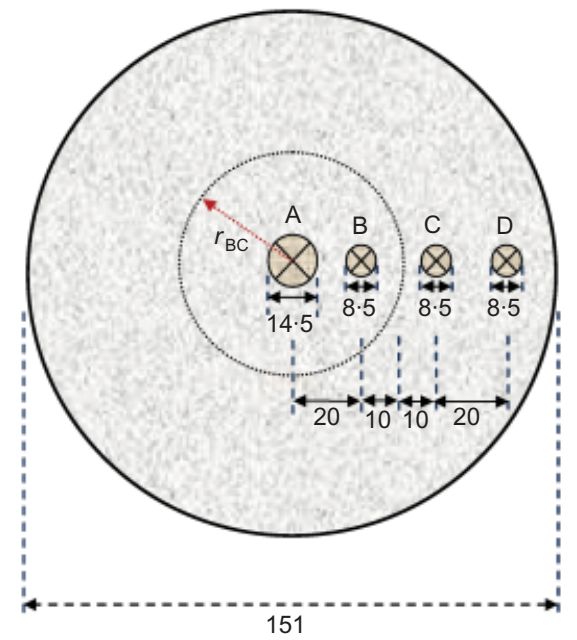

(b)

Fig. 2. (a) Modified $150 \mathrm{~mm}$ Rowe cell; (b) baseplate of Rowe cell showing locations of pore pressure measurement (dimensions in $\mathbf{m m}$ )

Table 1. Properties of kaolin

\begin{tabular}{l|l|c}
\hline Property & Standard & Value \\
\hline Index properties: & & \\
Liquid limit: \% & ASTM D4318 (2005) & 55 \\
Plastic limit: \% & ASTM D4318 (2005) & 27 \\
Specific gravity & ASTM D4318 (2005) & $2 \cdot 7$ \\
Percent sand: \% $\%$ & ASTM D6913 (2004) & 12 \\
Percent silt size: $\%$ & ASTM D422 (2007) & 26 \\
Percent clay size: $\%$ & ASTM D422 (2007) & 62 \\
Engineering properties: & & \\
Slope of consolidation line, $\lambda$, in $v-\ln p^{\prime}$ plot & ASTM D2435 (2004) & $0 \cdot 17$ \\
Slope of swelling line, $\kappa$, in $v-\ln p^{\prime}$ plot & ASTM D2435 (2004) & $0 \cdot 03$ \\
Specific volume at $p^{\prime} 1 \mathrm{kPa}$ on 1D consolidation line & ASTM D2435 (2004) & $2 \cdot 85$ \\
Friction angle, $\phi^{\prime}:$ degrees & ASTM D4767 (2004) & 27 \\
Slope of critical-state line in $q-p^{\prime}$ plot & ASTM D4767 (2004) & $1 \cdot 07$ \\
\hline
\end{tabular}


Table 2. Tests conducted with $150 \mathrm{~mm}$ modified Rowe cell

\begin{tabular}{l|c|c|c|c|c|c}
\hline Test no. & Sample diameter: $\mathrm{mm}$ & Drain diameter: $\mathrm{mm}$ & $n$ & SP: $\mathrm{kPa}$ & $\mathrm{VP}: \mathrm{kPa}$ & $\mathrm{VSR}=\frac{\mathrm{VP}}{\mathrm{SP}+\mathrm{VP}}$ \\
\hline 1 & 151 & $14 \cdot 5$ & $10 \cdot 41$ & 60 & 40 & $0 \cdot 4$ \\
2 & & & & 50 & 50 & $0 \cdot 5$ \\
3 & & & & 40 & 60 & $0 \cdot 6$ \\
\hline
\end{tabular}

Note: $n=R / r_{\mathrm{w}}$, where $R$ is the radius of the cell, and $r_{\mathrm{w}}$ is the radius of the drain.

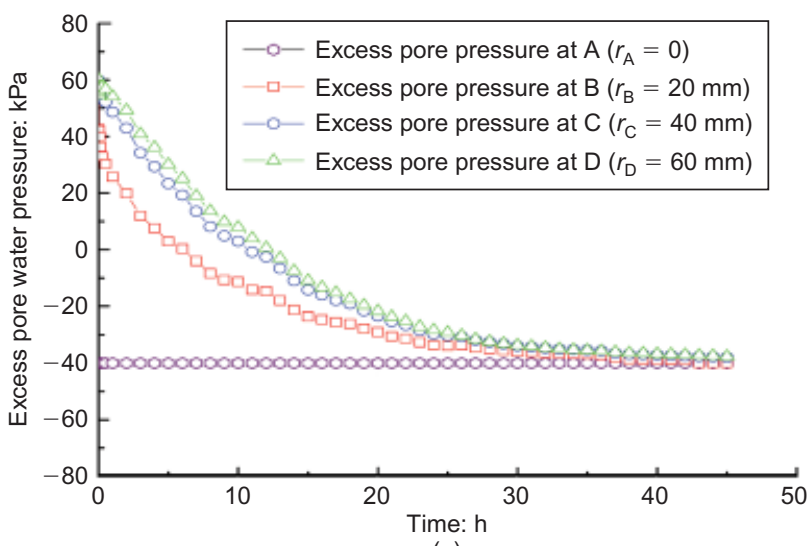

(a)

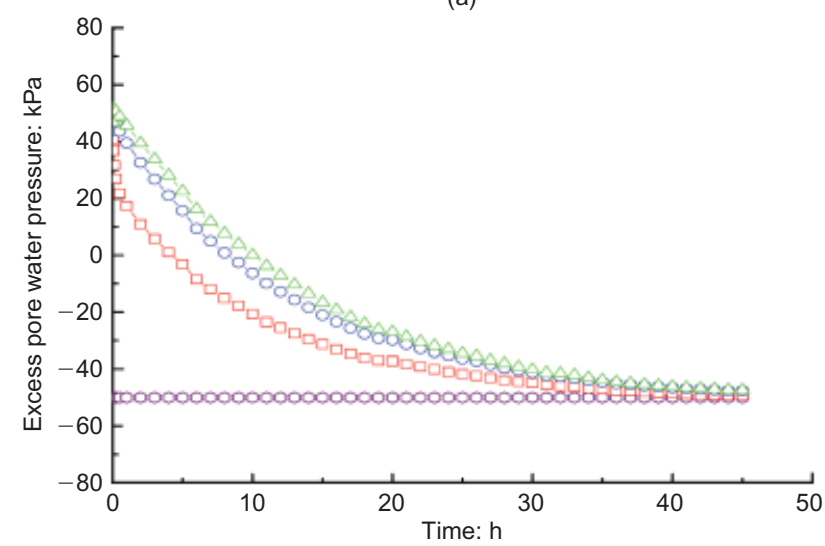

(b)

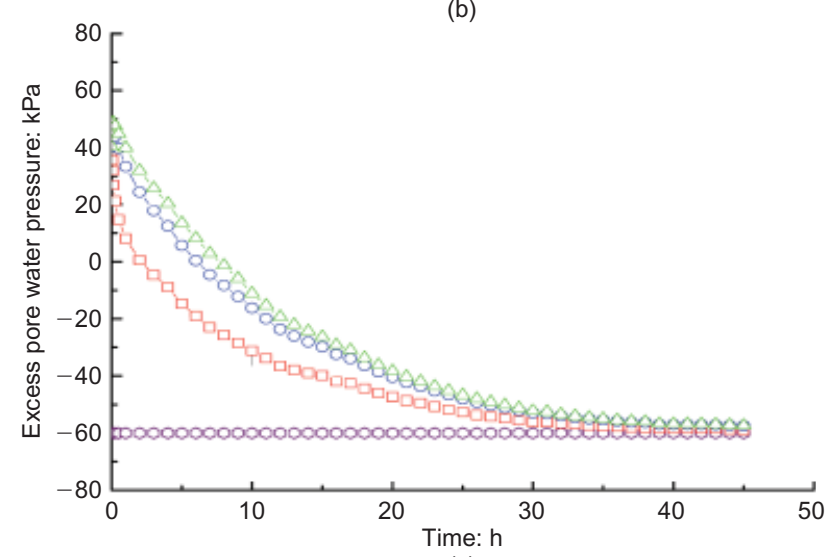

(c)

Fig. 3. Excess pore pressure distribution at different radii in $150 \mathrm{~mm}$ Rowe cell: (a) Test no. $1, \mathrm{VSR}=0.4$; (b) Test no. 2, $\mathrm{VSR}=0.5$; (c) Test no. 3, VSR $=0.6$

time at different radii for Tests $1-3$. The hydraulic gradient between locations $\mathrm{B}$ and $\mathrm{C}$ can now be calculated by

$$
i_{\mathrm{BC}}=\frac{1}{\gamma_{\mathrm{w}}} \frac{u_{\mathrm{C}}-u_{\mathrm{B}}}{r_{\mathrm{C}}-r_{\mathrm{B}}}
$$

In this equation, $i_{\mathrm{BC}}$ is the hydraulic gradient between regions $\mathrm{B}$ and $\mathrm{C}, \gamma_{\mathrm{w}}$ is the unit weight of water, $u_{\mathrm{B}}$ and $u_{\mathrm{C}}$ are the excess pore water pressures at a given time at regions $\mathrm{B}$ and $\mathrm{C}$ respectively, and $r_{\mathrm{B}}$ and $r_{\mathrm{C}}$ are the radial distances from the centreline to the centres of regions $\mathrm{B}$ and $\mathrm{C}$ respectively, measured from the centre of the cell (drain). The variation of excess pore pressure along the radius is non-linear; however, because the two measurement regions for excess pore pressure are very close to each other $(20 \mathrm{~mm}$ apart), the hypothesis of linear excess pore pressure variation between two points is justified.

The flow velocity $\left(v_{\mathrm{BC}}\right)$ was calculated halfway between regions $\mathrm{B}$ and $\mathrm{C}$, based on the rate of volume change of the soil sample with the internal and external radii $r_{\mathrm{BC}}$ and $R$ respectively: hence

$$
v_{\mathrm{BC}}=\frac{\partial \varepsilon}{\partial t} \frac{\left(R^{2}-r_{\mathrm{BC}}^{2}\right)}{2 r_{\mathrm{BC}}}
$$

where $\varepsilon$ is the axial strain.

The axial strain $(\varepsilon)$ is an averaged magnitude, and it is not radial or dimension-dependent. This is because the Rowe cell testing conducted in this study employed a rigid top disc, which mimics the equal-strain condition. As a result, the vertical strains in the sample are the same along the radii for any given depth, and equation (7) is valid for equal-strain conditions, where the vertical strains at any given depth are equal along the radii of the test specimen. Fig. 4 shows the relationship of flow velocity with hydraulic gradient for all tests. The equation based on the measured data can be represented by

$$
v=\alpha_{\mathrm{c}} i^{\beta}
$$

where $v$ is the flow velocity, $i$ is the hydraulic gradient, and $\alpha_{\mathrm{c}}$ and $\beta$ are constants that depend on the type of soil.

From Fig. $4, \alpha_{\mathrm{c}}$ and $\beta$ are defined to be $3 \cdot 2 \times 10^{-10} \mathrm{~m} / \mathrm{s}$

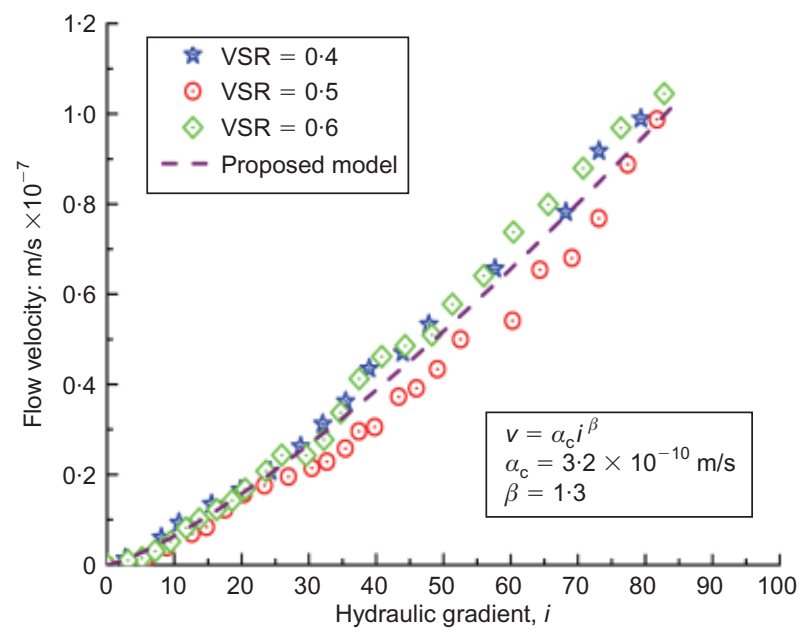

Fig. 4. Flow velocity-hydraulic gradient relationship 
and 1.3 respectively. These values represent the best fit to the average measured data. The curve of flow velocity against hydraulic gradient is obtained, here neglecting the horizontal displacements of the soil. The average measurement data (dashed line in Fig. 4) are used to calculate $\alpha_{c}$ and $\beta$. It should be mentioned that the use of average values can somehow smooth the differences between Darcian and non-Darcian flow, blurring the threshold hydraulic gradient in Hansbo's model (Hansbo, 1960) and lowering the value of the power law; however, this is the best way to minimise the errors in testing.

\section{RADIAL CONSOLIDATION MODEL INCORPORATING NON-DARCIAN FLOW AND VACUUM APPLICATION}

Hansbo's model (Hansbo, 1960, 2001) relies on an accurate measurement and calculation of the coefficient of permeability, $k_{\mathrm{h}}$, and the coefficient of radial consolidation, $c_{\mathrm{h}}$. Moreover, the threshold hydraulic gradient $i_{1}$ in the model needs to be accurately defined. In this section, the proposed exponential flow relationship (equation (8)), which is independent of any threshold hydraulic gradient, is used to develop an analytical model for radial consolidation that incorporates the effects of vacuum preloading. Apart from $\alpha_{\mathrm{c}}$ and $\beta, m_{\mathrm{v}}$ is the only soil parameter required in this model. Based on Fig. 4, the non-linear relationship of the flow velocity-hydraulic gradient is incorporated in the formulation of radial consolidation. By considering a unit cell, the hydraulic gradient $i$ in the radial direction at distance $r$ from the centre of the cell can be calculated from

$$
i=\frac{\partial h}{\partial r}=\frac{1}{\gamma_{\mathrm{w}}} \frac{\partial u}{\partial r}
$$

where $h$ is the head of water.

The flow rate, $\partial Q / \partial t$, can then be calculated, based on

$$
\begin{aligned}
\frac{\partial Q}{\partial t} & =v A=\alpha_{\mathrm{c}} i^{\beta} A \\
& =\alpha_{\mathrm{c}}\left(\frac{1}{\gamma_{\mathrm{w}}} \frac{\partial u}{\partial r}\right)^{\beta}(2 \pi r l) \\
\frac{\partial Q}{\partial t} & =\frac{\partial \varepsilon}{\partial t} \pi\left(R^{2}-r^{2}\right) l
\end{aligned}
$$

Equating equations (10) and (11) results in

$$
\frac{\partial u}{\partial r}=\gamma_{\mathrm{w}}\left(\frac{1}{2 \alpha_{\mathrm{c}}} \frac{\partial \varepsilon}{\partial t}\right)^{1 / \beta}\left(\frac{R^{2}-r^{2}}{r}\right)^{1 / \beta}
$$

Solving equation (12) (see the Appendix for the complete solution) leads to

$$
\begin{gathered}
\bar{u}=\left[(1-\beta)\left(-\frac{2 \alpha_{\mathrm{c}}}{m_{\mathrm{v}}}\right)\left(\frac{n^{2}-1}{2 n^{2}} \frac{R^{2}}{\eta \gamma_{\mathrm{w}}}\right)^{\beta} t\right. \\
\left.+\left(\bar{u}_{0}+P_{0}\right)^{1-\beta}\right]^{1 /(1-\beta)}-P_{0}
\end{gathered}
$$

$$
\begin{aligned}
u^{\prime}= & \eta_{\mathrm{s}}\left(\frac{\alpha_{\mathrm{c}}}{\alpha_{\mathrm{c}}^{\prime}}\right)^{1 / \beta}\left(\frac{n^{2}-1}{2 n^{2}} \frac{R^{2}}{\eta}\right) \\
& \times\left[(1-\beta)\left(-\frac{2 \alpha_{\mathrm{c}}}{m_{\mathrm{v}}}\right)\left(\frac{n^{2}-1}{2 n^{2}} \frac{R^{2}}{\eta \gamma_{\mathrm{w}}}\right)^{\beta} t\right. \\
& \left.+\left(\bar{u}_{0}+P_{0}\right)^{1-\beta}\right]^{1 /(1-\beta)}-P_{0} \\
\text { for } r_{\mathrm{w}} \leqslant & r \leqslant r_{\mathrm{s}} ; \\
u= & \eta_{\mathrm{n}}\left(\frac{n^{2}-1 R^{2}}{2 n^{2}} \frac{R^{2}}{\eta}\right]^{1 /(1-\beta)} \\
& \times\left[(1-\beta)\left(-\frac{2 \alpha_{\mathrm{c}}}{m_{\mathrm{v}}}\right)\left(\frac{n^{2}-1}{2 n^{2} \frac{R^{2}}{\eta \gamma_{\mathrm{w}}}}\right)^{\beta} t\right. \\
& +\left(\bar{u}_{0}+P_{0}\right)^{1-\beta} P_{0}
\end{aligned}
$$

for $r_{\mathrm{s}} \leqslant r \leqslant R$; and

$$
\begin{aligned}
\varepsilon= & -m_{\mathrm{v}}\left\{\left[(1-\beta)\left(-\frac{2 \alpha_{\mathrm{c}}}{m_{\mathrm{v}}}\right)\left(\frac{n^{2}-1}{2 n^{2}} \frac{R^{2}}{\eta \gamma_{\mathrm{w}}}\right)^{\beta} t\right.\right. \\
& \left.\left.+\left(\bar{u}_{0}+P_{0}\right)^{1-\beta}\right]^{1 /(1-\beta)}\right\}-\left(\bar{u}_{0}+P_{0}\right)
\end{aligned}
$$

where $\bar{u}$ is the average excess pore water pressure in the unit cell; $u^{\prime}$ and $u$ are the excess pore water pressures within and outside the smear zone respectively, for a given time; $m_{\mathrm{v}}$ is the coefficient of the soil volume compressibility; $\bar{u}_{0}$ is the initial average excess pore water pressure in the unit cell; $P_{0}$ is the magnitude of the vacuum pressure at the drain/soil interface; $\alpha_{c}^{\prime}$ is the substitute of $\alpha_{c}$ in equation (8) for the flow relationship in the smear zone; $r_{\mathrm{w}}$ and $r_{\mathrm{S}}$ are the radii of the drain and smear zone respectively; $n=R / r_{\mathrm{w}}$; and $\eta, \eta_{\mathrm{s}}$ and $\eta_{\mathrm{n}}$ are coefficients which are defined in the Appendix.

\section{VALIDATION OF THE NON-DARCIAN MODEL}

To validate the proposed radial consolidation model, the model predictions were compared with the measured data, predictions made by a radial consolidation model based on Darcy's flow (Hansbo, 2001), and a radial consolidation model based on non-linear flow proposed by Hansbo (1960, 2001). Based on Darcian flow, equations (17) and (18) can be used to calculate the excess pore water pressures in the smear and undisturbed zones respectively (Indraratna et al., 2005b)

$$
\begin{aligned}
u^{\prime}= & \frac{k_{\mathrm{h}}}{k_{\mathrm{h}}^{\prime}} \frac{\left(\bar{u}_{0}+P_{0}\right)}{\mu R^{2}} \exp \left(-\frac{2 c_{\mathrm{h}} t}{\mu R^{2}}\right)\left[R^{2} \ln \left(\frac{r}{r_{\mathrm{w}}}\right)-\frac{\left(r^{2}-r_{\mathrm{w}}^{2}\right)}{2}\right] \\
& -P_{0}
\end{aligned}
$$

for $r_{\mathrm{W}} \leqslant r \leqslant r_{\mathrm{s}}$; and 


$$
\begin{aligned}
u= & \left(\frac{\bar{u}_{0}+P_{0}}{\mu R^{2}}\right) \exp \left(-\frac{2 c_{\mathrm{h}} t}{\mu R^{2}}\right) \\
& \times\left\{\begin{array}{l}
{\left[R^{2} \ln \left(\frac{r}{r_{\mathrm{s}}}\right)-\frac{\left(r^{2}-r_{\mathrm{s}}^{2}\right)}{2}\right]} \\
+\frac{k_{\mathrm{h}}}{k_{\mathrm{h}}^{\prime}}\left[R^{2} \ln \left(\frac{r_{\mathrm{s}}}{r_{\mathrm{w}}}\right)-\frac{\left(r_{\mathrm{s}}^{2}-r_{\mathrm{w}}^{2}\right)}{2}\right]
\end{array}\right\}-P_{0}
\end{aligned}
$$

for $r_{\mathrm{s}} \leqslant r \leqslant R$, where

$$
\begin{aligned}
\mu= & \frac{n^{2}}{n^{2}-1}\left[\ln \left(\frac{n}{s}\right)+\frac{k_{\mathrm{h}}}{k_{\mathrm{h}}^{\prime}} \ln (s)-\frac{3}{4}\right]+\frac{s^{2}}{n^{2}-1}\left(1-\frac{s^{2}}{4 n^{2}}\right) \\
& +\frac{k_{\mathrm{h}}}{k_{\mathrm{h}}^{\prime}} \frac{1}{n^{2}-1}\left(\frac{s^{4}-1}{4 n^{2}}-s^{2}+1\right)
\end{aligned}
$$

$k_{\mathrm{h}}$ and $k_{\mathrm{h}}^{\prime}$ are the coefficients of permeability in the horizontal direction within the undisturbed and smear zones respectively, and $c_{\mathrm{h}}$ is the coefficient of radial consolidation.

Average excess pore water pressure and axial strain based on Darcy flow at any given time in the unit cell can be calculated by equations (20) and (21) respectively (Indraratna et al., 2005b).

$$
\begin{aligned}
& \bar{u}=\left(\bar{u}_{0}+P_{0}\right) \exp \left(-\frac{2 c_{\mathrm{h}} t}{\mu R^{2}}\right)-P_{0} \\
& \varepsilon=-m_{\mathrm{v}}\left(\bar{u}_{0}+P_{0}\right)\left[\exp \left(-\frac{2 c_{\mathrm{h}} t}{\mu R^{2}}\right)-1\right]
\end{aligned}
$$

Based on Hansbo's (1960) non-linear flow relationship (equation (1); Hansbo, 1960), equations (22)-(25) can be formulated for the excess pore water pressures within and outside the smear zone, the average excess pore water pressure, and the axial strain respectively. Note that the original Hansbo (1960) equations have now been revised to include vacuum pressure $\left(P_{0}\right)$. To formulate equations $(22)-$ (25), the same procedure as explained in the Appendix can be followed, and $\beta$ and $\alpha_{\mathrm{c}} / \alpha_{\mathrm{c}}^{\prime}$ are substituted by $m$ and $k_{\mathrm{h}} / k_{\mathrm{h}}^{\prime}$ respectively.

$$
\begin{aligned}
u^{\prime}= & \eta_{\mathrm{s}}\left(\frac{k_{\mathrm{h}}}{k_{\mathrm{h}}^{\prime}}\right)^{1 / m}\left(\frac{n^{2}-1}{2 n^{2}} \frac{R^{2}}{\eta}\right) \\
& \times\left[(1-m)\left(-\frac{2 c_{\mathrm{h}} \gamma_{\mathrm{w}}}{m i_{1}^{m-1}}\right)\left(\frac{n^{2}-1}{2 n^{2}} \frac{R^{2}}{\eta \gamma_{\mathrm{w}}}\right)^{m} t\right. \\
& \left.+\left(\bar{u}_{0}+P_{0}\right)^{1-m}\right]^{1 /(1-m)}-P_{0}
\end{aligned}
$$

for $r_{\mathrm{W}} \leqslant r \leqslant r_{\mathrm{s}}$;

$$
\begin{aligned}
u= & \eta_{\mathrm{n}}\left(\frac{n^{2}-1}{2 n^{2}} \frac{R^{2}}{\eta}\right) \\
& \times\left[(1-m)\left(-\frac{2 c_{\mathrm{h}} \gamma_{\mathrm{w}}}{m i_{1}^{m-1}}\right)\left(\frac{n^{2}-1}{2 n^{2}} \frac{R^{2}}{\eta \gamma_{\mathrm{w}}}\right)^{m} t\right. \\
& \left.+\left(\bar{u}_{0}+P_{0}\right)^{1-m}\right]^{1 /(1-m)}-P_{0}
\end{aligned}
$$

for $r_{\mathrm{s}} \leqslant r \leqslant R$

$$
\begin{aligned}
\bar{u}= & {\left[(1-m)\left(-\frac{2 c_{h} \gamma_{w}}{m i_{l}^{m-1}}\right)\left(\frac{n^{2}-1}{2 n^{2}} \frac{R^{2}}{\eta \gamma_{\mathrm{w}}}\right)^{m} t\right.} \\
& \left.+\left(\bar{u}_{0}+P_{0}\right)^{1-m}\right]^{1 /(1-m)}-P_{0} \\
\varepsilon= & \left(-\frac{k_{\mathrm{h}}}{c_{\mathrm{h}} \gamma_{\mathrm{w}}}\right) \\
& \times\left\{\left[(1-m)\left(-\frac{2 c_{\mathrm{h}} \gamma_{\mathrm{w}}}{m i_{1}^{m-1}}\right)\left(\frac{n^{2}-1}{2 n^{2}} \frac{R^{2}}{\eta \gamma_{\mathrm{w}}}\right)^{m} t\right.\right. \\
& \left.\left.+\left(\bar{u}_{0}+P_{0}\right)^{1-m}\right]^{1 /(1-m)}-\left(\bar{u}_{0}+P_{0}\right)\right\}
\end{aligned}
$$

To determine the soil parameters $\left(m_{\mathrm{V}}\right.$ and $\left.c_{\mathrm{h}}\right)$, a radial consolidation test $(\mathrm{SP}=100 \mathrm{kPa}$ and $\mathrm{VP}=0 \cdot 0)$ with a standard $75 \mathrm{~mm}$ Rowe cell was conducted, and the value of $m_{\mathrm{v}}$ was calculated to be $0.97 \mathrm{~m}^{2} / \mathrm{MN}$. Based on the settlement data, $c_{\mathrm{h}}$ was calculated according to three different methods: A, the steepest tangent method (Vinod et al., 2010); B, the square root method (Sridharan et al., 1996); and C, the loglog method (Robinson, 2009). In addition, by assuming

\begin{tabular}{|c|c|c|c|c|c|c|c|c|c|}
\hline \multirow[t]{3}{*}{ Test no. } & \multirow{3}{*}{$\begin{array}{c}\text { Sample } \\
\text { diameter: } \\
\mathrm{mm}\end{array}$} & \multirow{3}{*}{$\begin{array}{c}\text { Drain } \\
\text { diameter: } \mathrm{mm}\end{array}$} & \multirow[t]{3}{*}{$n$} & \multirow{3}{*}{$\begin{array}{l}\mathrm{SP}: \\
\mathrm{kPa}\end{array}$} & \multirow{3}{*}{$\begin{array}{l}\mathrm{VP}: \\
\mathrm{kPa}\end{array}$} & \multicolumn{4}{|c|}{$c_{\mathrm{h}}: \mathrm{m}^{2} /$ year } \\
\hline & & & & & & \multicolumn{3}{|c|}{ Rowe cell (radial consolidation) } & \multirow{2}{*}{$\begin{array}{c}\text { Rowe cell (vertica } \\
\text { consolidation) }\end{array}$} \\
\hline & & & & & & $\begin{array}{l}(\mathrm{A}) \\
\text { Steepest } \\
\text { tangent } \\
\text { method }\end{array}$ & $\begin{array}{c}\text { (B) } \\
\text { Square root } \\
\text { method }\end{array}$ & $\begin{array}{l}\text { (C) } \\
\text { Log-log } \\
\text { method }\end{array}$ & \\
\hline 4 & $75 \cdot 5$ & $7 \cdot 5$ & $10 \cdot 07$ & 100 & 0 & $4 \cdot 90$ & $2 \cdot 91$ & $2 \cdot 23$ & $1 \cdot 83$ \\
\hline
\end{tabular}
$c_{\mathrm{h}}=c_{\mathrm{v}}$, a vertical consolidation test $(\mathrm{SP}=100 \mathrm{kPa})$ with the $75 \mathrm{~mm}$ Rowe cell was conducted, and the logarithm-of-time method was employed to determine $c_{\mathrm{h}}$ (approach D). Atkinson et al. (1987) suggest that the high vertical compression of a remoulded soil specimen during testing makes the induced anisotropy even, when compared with an undisturbed specimen. Therefore, in the current study, the effects of anisotropy can be considered as small, and this is reflected by the measured ratio of horizontal to vertical coefficients of consolidation $\left(c_{\mathrm{h}} / c_{\mathrm{V}}\right)$ in the range $1 \cdot 05-1 \cdot 10$. The related information for the above four approaches is summarised in Table 3. To use Hansbo's non-linear model, the values of $i_{0}$ and $i_{1}$ based on Fig. 4 were determined to be 15 and 45 respectively, and for the value of $m$ the general value of 1.5 recommended by Hansbo (2001) is used.

Table 3. Values of $c_{\mathrm{h}}$ calculated based on different approaches 
To validate the proposed model, measured data from a test with a combination of surcharge and vacuum pressure were also obtained using a $75 \mathrm{~mm}$ Rowe cell, as shown in Table 4. The average excess pore water pressure and axial settlement were compared with the predictions based on the author's model, the model based on Darcian flow, and the model based on Hansbo's non-Darcian flow. Fig. 5(a) compares the measured average excess pore water pressure with the predictions from the proposed model (equations (14) and (15)) and the Darcian-based model (equations (17) and (18)), considering the four different approaches (A, B, C and D) for the calculation of $c_{\mathrm{h}}$. Fig. 5(b) shows the comparisons between the laboratory results and the predictions based on Hansbo's non-linear flow relationship (equations (22) and (23)). The time-dependent axial strains based on equations (16), (21) and (25) are presented in Fig. 6, comparing the predictions based on the proposed model, the Darcian-based model and Hansbo's non-Darcian-based model. The predictions of Hansbo's non-Darcian-based model show faster

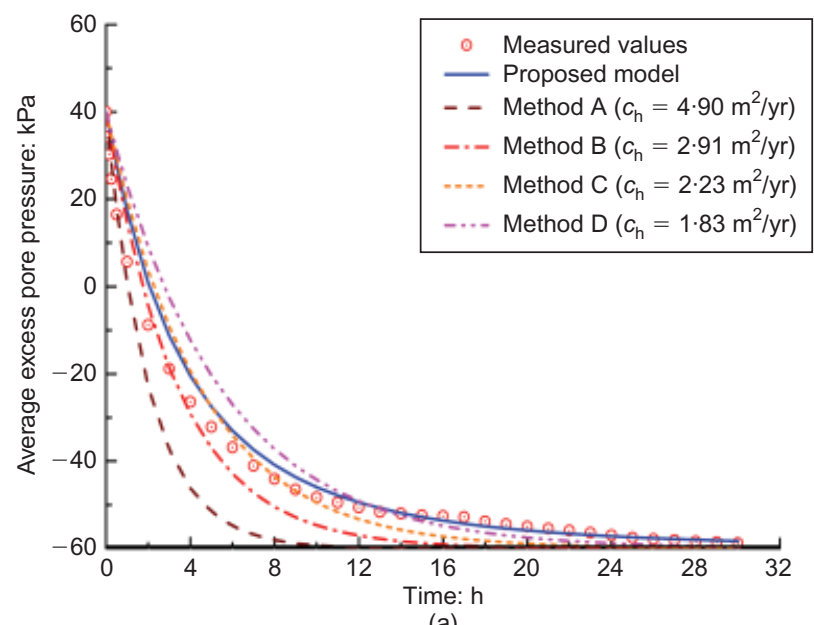

(a)

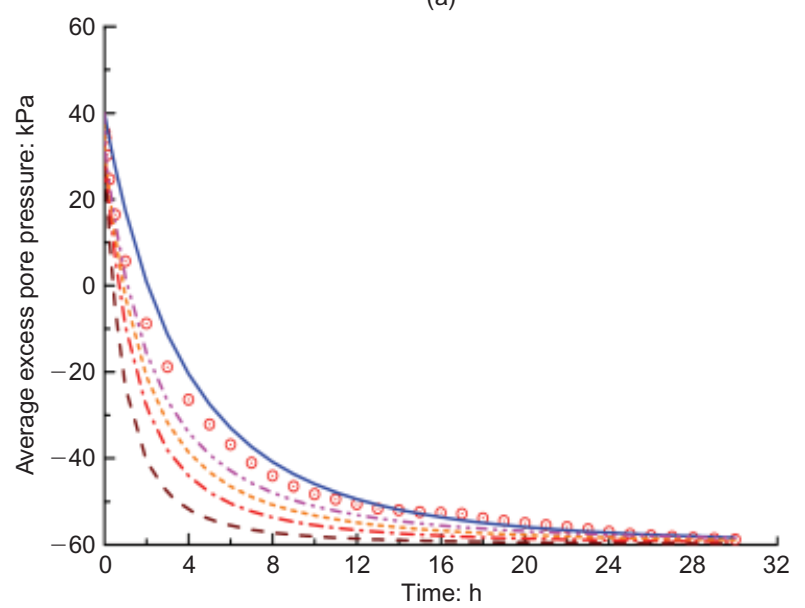

(b)

Fig. 5. Average excess pore waster pressure dissipation in $75 \mathrm{~mm}$ Rowe cell: (a) comparison with Darcian-based model; (b) comparison with Hansbo's non-Darcian-based model

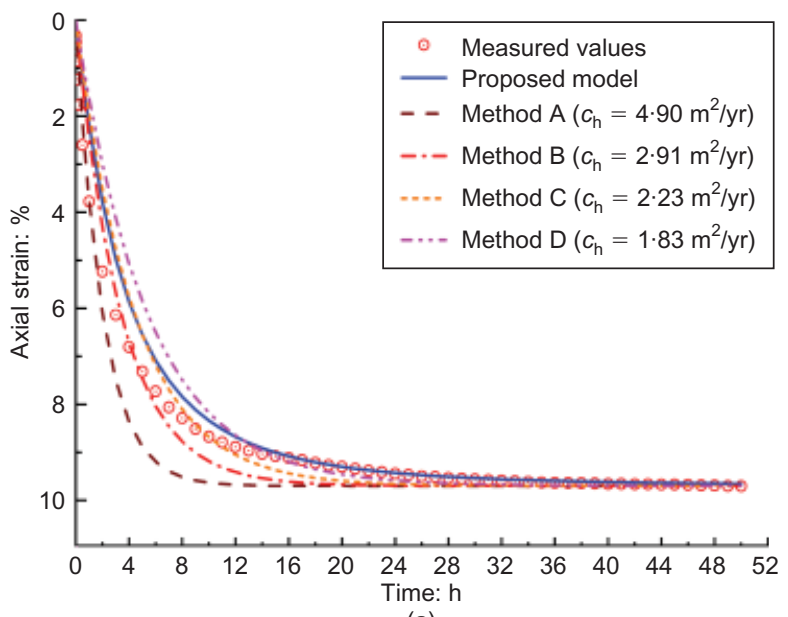

(a)

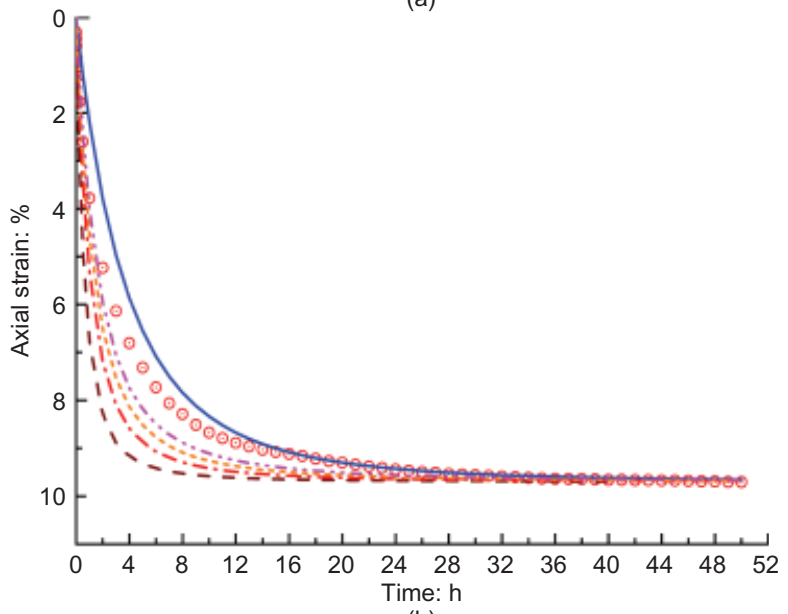

(b)

Fig. 6. Axial strain in $75 \mathrm{~mm}$ Rowe cell: (a) comparison with Darcian-based model; (b) comparison with Hansbo's nonDarcian-based model

dissipation of excess pore water pressure and higher settlement for all values of $c_{\mathrm{h}}$ at a given time, compared with the proposed model and the Darcian-based model. When the hydraulic gradient is relatively high, Darcian flow provides better agreement, whereas when the hydraulic gradient is relatively low, non-Darcian flow provides better agreement. This is because, under higher hydraulic gradients, Hansbo's non-linear flow relationship yields higher water flow velocity than the conventional Darcy's law and proposed model. This elucidates the limitation of Hansbo's solution when the flow during consolidation can be a combination of Darcian and non-Darcian conditions. It is also implied in these figures that the method used for defining the value of $c_{\mathrm{h}}$ also has an effect on this comparison. Good agreement between the predictions of the proposed model and the measured data can be observed, as well as a sensitivity of the existing models to the method of $c_{\mathrm{h}}$ calculation, where the calculated $c_{\mathrm{h}}$ can vary by more than $250 \%$ (see Table 3 ) adopting the various approaches (A, B, C and D).

Table 4. Radial consolidation test using $75 \mathrm{~mm}$ Rowe cell

\begin{tabular}{l|c|c|c|c|c|c|c}
\hline Test no. & Sample diameter: $\mathrm{mm}$ & Drain diameter: $\mathrm{mm}$ & $n$ & $\mathrm{SP}: \mathrm{kPa}$ & $\mathrm{VP}: \mathrm{kPa}$ & $\mathrm{SP}+\mathrm{VP}: \mathrm{kPa}$ & $\mathrm{VSR}=\frac{\mathrm{VP}}{\mathrm{SP}+\mathrm{VP}}$ \\
\hline 5 & 75.5 & $7 \cdot 5$ & $10 \cdot 07$ & 40 & 60 & 100 & 0.6 \\
\hline
\end{tabular}




\section{ADVANTAGES OF THE MODEL AND PRACTICAL IMPLICATIONS}

During the conceptual design, when observational field data are unavailable, parameters such as the coefficient of soil volume compressibility $m_{\mathrm{v}}$, the coefficient of consolidation $c_{\mathrm{h}}$ and the coefficient of permeability $k_{\mathrm{h}}$ need to be evaluated first. Independent tests are usually used to calculate $c_{\mathrm{h}}$ and $k_{\mathrm{h}}$, and often result in different values of $c_{\mathrm{h}}$ and $k_{\mathrm{h}}$. Of these three parameters, $m_{\mathrm{v}}$ is considered to be the most reliable. It does not depend on the test procedures or the calculation method, and using this parameter instead of $c_{\mathrm{h}}$ eliminates the uncertainties related to the calculation of $c_{\mathrm{h}}$

Capturing the flow relationship using the above technique not only eliminates the errors and uncertainties that could probably occur while using conventional procedures to calculate permeability; it also provides a more realistic flow relationship during consolidation. With the proposed technique, $\alpha_{\mathrm{c}}$ and $\beta$ define the seepage flow behaviour under the entire range of hydraulic gradient, for both field and laboratory conditions. Another advantage of the proposed consolidation model is that it needs only $m_{\mathrm{v}}$ to be determined, which can easily be calculated, based on the settlement and applied pressure. Moreover, in comparison with Hansbo's model (Hansbo, 2001), the proposed flow relationship and the consolidation model have the following advantages.

(a) Although Hansbo (2001) stated that the non-linear part of the flow relationship can be accurately used for the entire range from low to high hydraulic gradients, the threshold hydraulic gradient $\left(i_{1}\right)$ must still be accurately defined to calculate $i_{0}$ and $m$. Determining this gradient is not an easy task, and may not be accurate unless the flow relationship is available. The wide range of reported values for $i_{1}$ (e.g. Hansbo, 1960; Dubin \& Moulin, 1986) shows that $i_{1}$ changes considerably in different soil, and inaccuracy in defining $i_{1}$ might significantly decrease the accuracy of the predictions. In contrast, in the author's proposed model, there is no threshold, and a non-linear flow relationship can be used to describe the entire range of hydraulic gradients.

(b) The non-linear part of Hansbo's model is applicable to field conditions (Hansbo, 1960) only when the hydraulic gradient is small. For cases where the hydraulic gradient is large, such as in projects where a high surcharge preloading is required, or when the behaviour of the soil close to the drains is of interest, Hansbo's non-linear model may deviate from the measured data, whereas the proposed model is able to capture the entire range of hydraulic gradients applicable to both laboratory and field conditions.

\section{APPLICATION TO A CASE STUDY}

To demonstrate the accuracy of the proposed model predictions under field conditions, the measured data obtained from the reclamation area at the Port of Brisbane (Australia) were analysed. The site was divided into eight areas (Fig. 7) and a combination of conventional surcharge

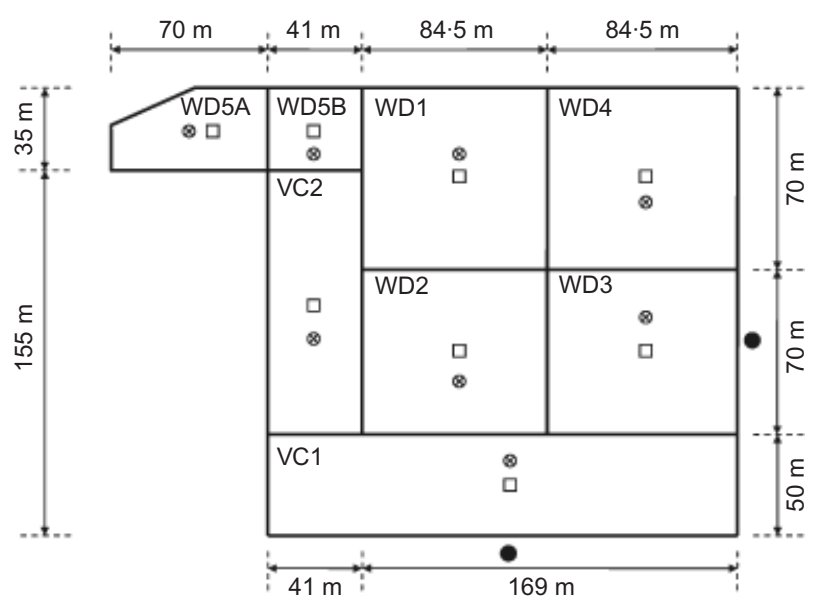

- Surface settlement plates

(2) Piezometers

- Inclinometers

Fig. 7. Subdivisions of reclaimed area at Port of Brisbane

and vertical drains (PVDs) was used for the soil improvement scheme. In two of the subdivisions ( $\mathrm{VC} 1$ and $\mathrm{VC} 2$ in Fig. 7), vacuum pressure was used in conjunction with surcharge fill and vertical drains. In this section, the measured data in non-vacuum areas (WD2 and WD4) were employed to determine the flow relationship, whereas the measured data from the vacuum area (VC1) were compared with the predictions based on the proposed and conventional models.

The characteristics of ground improvement for areas WD2, WD4 and VC1 are summarised in Table 5, and the soil properties and general ground profile for the reclamation area reported by Indraratna et al. (2011) are presented in Fig. 8. The soil profile and thickness of the soil layers for sections WD2, WD4 and VC1 are given in Table 6. Embankment height, measured surface settlement and measured excess pore water pressure for areas WD2 and WD4 are shown in Fig. 9. Surface settlement and pore water pressure at depths of $9.2 \mathrm{~m}$ and $14 \mathrm{~m}$ were measured at the centre of subdivisions WD2 and WD4 respectively. From Fig. 9, the data after attaining the maximum excess pore water pressures were used to determine the seepage flow relationship. The average hydraulic gradient in each area was calculated based on the excess pore water pressures at the drain/soil interface and at the drain influence zone. The seepage velocity was calculated halfway between these two locations, based on equation (7). Fig. 10 represents the associated $v-i$ plots for areas WD2 and WD4. The values of $\alpha_{\mathrm{c}}$ and $\beta$ were calculated to be $1 \cdot 1 \times 10^{-10} \mathrm{~m} / \mathrm{s}$ and 1.35 respectively, which represent the best fit to the average data in areas WD2 and WD4.

Surface settlement and pore water pressure at a depth of $10 \cdot 1 \mathrm{~m}$ were measured at the centre of subdivision VC1. In the analysis, the ratio $\alpha_{\mathrm{c}} / \alpha_{\mathrm{c}}^{\prime}$ and $s$ were taken as 2 and 3 respectively. Based on the settlement curves for areas WD2

Table 5. PVD characteristics and improvement scheme at Port of Brisbane

\begin{tabular}{|c|c|c|c|c|c|c|}
\hline Section & Drain type & $\begin{array}{c}\text { Drain length: } \\
\text { m }\end{array}$ & $\begin{array}{l}\text { Drain spacing in } \\
\text { square pattern: } m\end{array}$ & $\begin{array}{l}\text { Clay thickness: } \\
\text { m }\end{array}$ & $\begin{array}{l}\text { Total fill } \\
\text { height: } \mathrm{m}\end{array}$ & Treatment scheme \\
\hline $\begin{array}{l}\text { WD2 } \\
\text { WD4 } \\
\text { VC1 }\end{array}$ & $\begin{array}{l}\text { Circular drains with } 34 \mathrm{~mm} \text { diameter } \\
\text { Band drains }\left(100 \times 4 \mathrm{~mm}^{2}\right) \\
\text { Circular drains with } 34 \mathrm{~mm} \text { diameter }\end{array}$ & $\begin{array}{l}22 \cdot 5-27 \cdot 5 \\
27 \cdot 0-28 \cdot 7 \\
14 \cdot 0-26 \cdot 5\end{array}$ & $\begin{array}{l}1 \cdot 3 \\
1 \cdot 3 \\
1 \cdot 2\end{array}$ & $\begin{array}{r}20 \cdot 0-23 \cdot 5 \\
22 \cdot 5-24 \cdot 5 \\
9 \cdot 0-21 \cdot 0\end{array}$ & $\begin{array}{c}7-7 \cdot 2 \\
6 \cdot 1 \\
3 \cdot 2\end{array}$ & $\begin{array}{l}\text { Surcharge } \\
\text { Surcharge } \\
\text { Surcharge }+65 \mathrm{kPa} \\
\text { vacuum }\end{array}$ \\
\hline
\end{tabular}




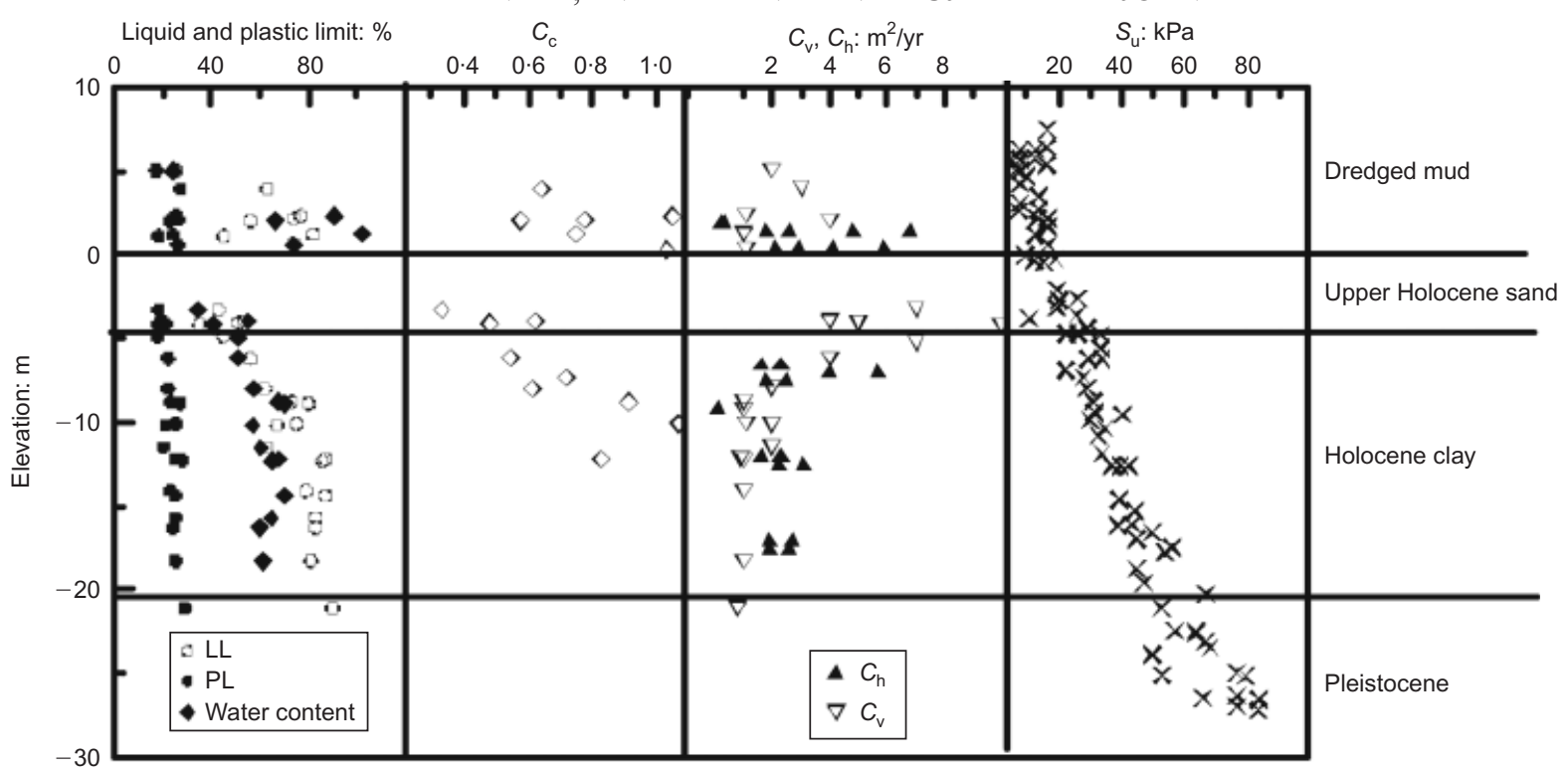

Fig. 8. Soil properties and profile at reclamation site, Port of Brisbane (after Indraratna et al., 2011)

Table 6. Soil profiles for individual sections at the Port of Brisbane

\begin{tabular}{l|c|c|c|c}
\hline \multirow{2}{*}{ Area } & \multicolumn{4}{|c}{ Layer thickness: m } \\
\cline { 2 - 5 } & Dredged mud & $\begin{array}{c}\text { Upper Holocene } \\
\text { sand }\end{array}$ & $\begin{array}{c}\text { Upper Holocene } \\
\text { clay }\end{array}$ & $\begin{array}{c}\text { Lower Holocene } \\
\text { clay }\end{array}$ \\
\hline WD2 & $1-2 \cdot 5$ & $1-3$ & $2-5$ & $18-20$ \\
WD4 & $1 \cdot 5-2 \cdot 2$ & $1-2$ & $1 \cdot 5-3 \cdot 5$ & $18-23$ \\
VC1 & $2-3$ & $2-3$ & $2-3$ & $5-18$ \\
\hline
\end{tabular}

and WD4, the coefficient of volume compressibility $m_{\mathrm{v}}$ was back-calculated to be $1.0 \mathrm{~m}^{2} / \mathrm{MN}$. The average value of $c_{\mathrm{h}}$ for clay was back-calculated based on the settlement curves for areas WD2 and WD4, adopting three different approaches. The best-fit trend for the entire predicted settlement curves with the measured data was adopted as Approach I. The well-known technique proposed by Asaoka (1978) was employed as Approach II to predict the ultimate primary consolidation and the achieved degree of consolidation enabling back-calculation of $c_{\mathrm{h}}$. Approach III was similar to Approach II, but instead of Asaoka's method, the hyperbolic method (Tan et al., 1991) was employed. Based on these three approaches, $c_{\mathrm{h}}$ was back-calculated to be $2 \cdot 0$, 1.3 and $0.5 \mathrm{~m}^{2} /$ year for Approaches I, II and III respectively. For Hansbo's model, the general value $m=1.5$ recommended by Hansbo (2001) was used, and from Fig. 10, $i_{0}$ and $i_{1}$ were determined to be 4 and 12 respectively.

Figure 11 shows the height of the embankment, the associated settlement and pore pressure data at the centreline of Section VC1, in comparison with the predictions made from the conventional Darcian-based model, and Hansbo's non-Darcian-based model during the period when the maximum height of the embankment and vacuum pressure were applied to the soil. The value of $c_{\mathrm{h}}$ determined from Approach I $\left(2.0 \mathrm{~m}^{2} /\right.$ year $)$ was used to calculate the predictions made by the existing models, as shown in Fig. 11. Both the Darcian-based and Hansbo non-Darcian-based models overestimate the settlement and underestimate the excess pore water pressure, in comparison with the proposed nonDarcian model. Figs 12 and 13 are the same as Fig. 11, except that the values of $c_{\mathrm{h}}\left(1.3\right.$ and $0.5 \mathrm{~m}^{2} /$ year $)$ used in the existing model predictions are based on Approaches II and III respectively. Fig. 12 shows that adopting Approach II for this case study results in better predictions by the existing models compared with those based on Approaches I and III. It is shown that the different methods adopted to back-calculate the coefficient of radial consolidation may result in different predictions by the existing models, whereas the proposed model is not affected by such a procedure. Comparison of the results plotted in Figs 11-13 implies that, for the existing models, the same question arises for the field prediction based on different approaches used to back-calculate $c_{\mathrm{h}}$. In contrast, Figs 11-13 show that the proposed model can accurately predict the settlement, albeit underestimating the excess pore water pressure.

\section{CONCLUSION}

Laboratory radial consolidation tests subjected to vacuum and surcharge loading using a modified Rowe cell were conducted to determine seepage flow characteristics during radial consolidation. Based on measurement of the excess pore water pressure, a non-linear relationship between flow velocity and hydraulic gradient was proposed for the entire consolidation process. The advantages of the proposed flow relationship can be summarised as follows: (a) it provides more realistic flow behaviour during consolidation; and (b) in contrast to the relationship proposed by Hansbo (1960), the threshold hydraulic gradient is not required to differentiate between the linear and non-linear flow relationships.

Classical radial consolidation models often rely on the accurate calculation of $c_{\mathrm{h}}$. Different methods for determining $c_{\mathrm{h}}$ provide different values. In this study, it is shown that the value of $c_{\mathrm{h}}$ can vary by more than $250 \%$ in the laboratory, 


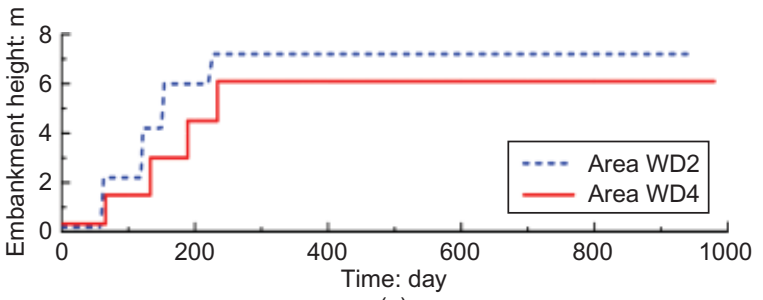

(a)

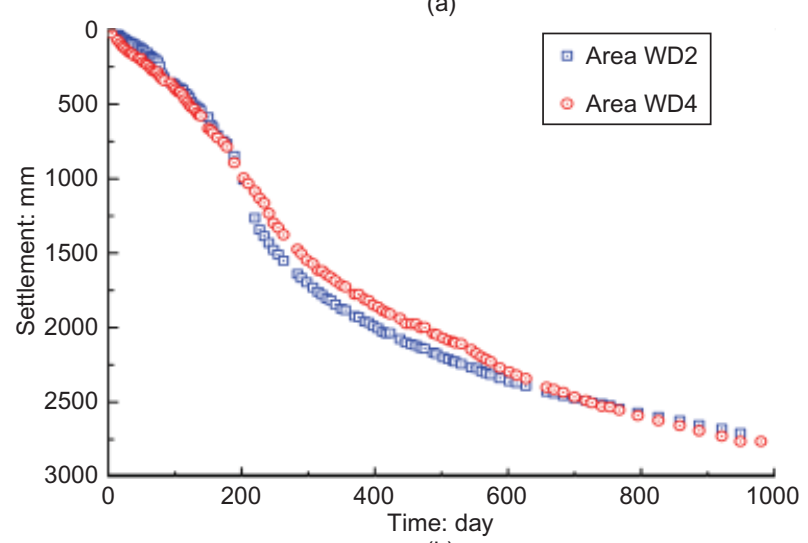

(b)

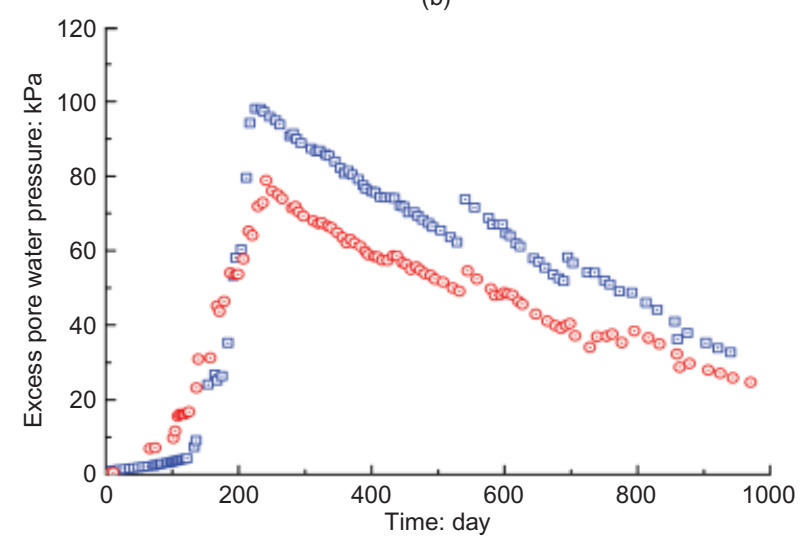

(c)

Fig. 9. (a) Embankment height, (b) settlement and (c) excess pore water pressure for sections WD2 and WD4, Port of Brisbane, Australia

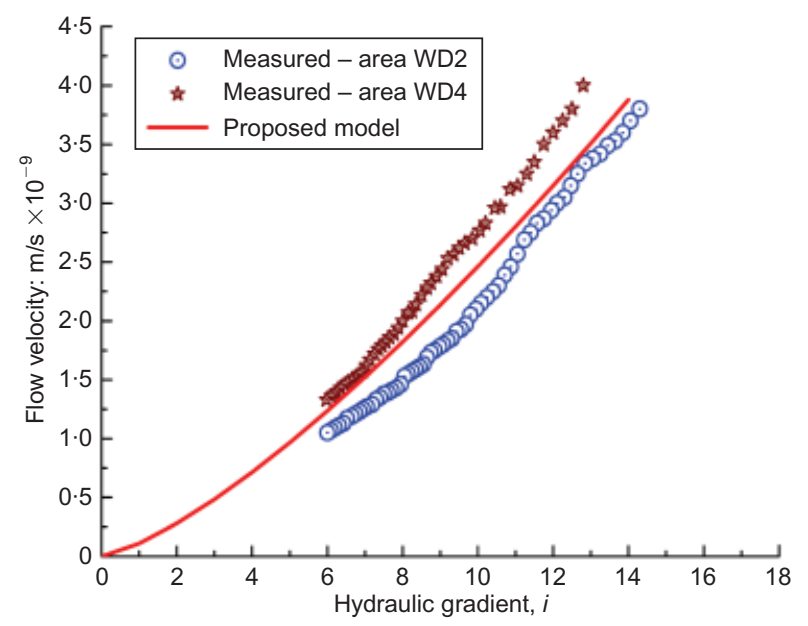

Fig. 10. Flow velocity-hydraulic gradient relationship for areas WD2 and WD4 at Port of Brisbane

resulting in uncertainties in the prediction of excess pore pressure and settlement. A similar issue was shown for field prediction, based on the different approaches used to backcalculate the coefficient of radial consolidation. In contrast,

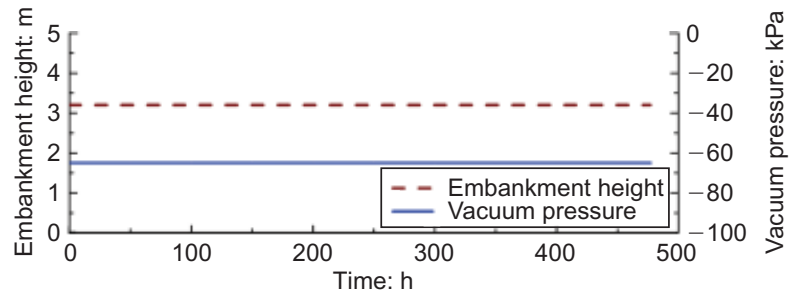

(a)

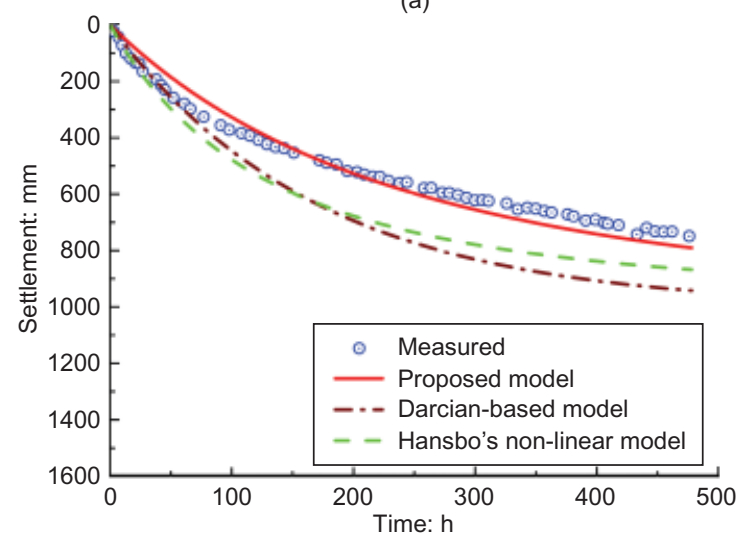

(b)

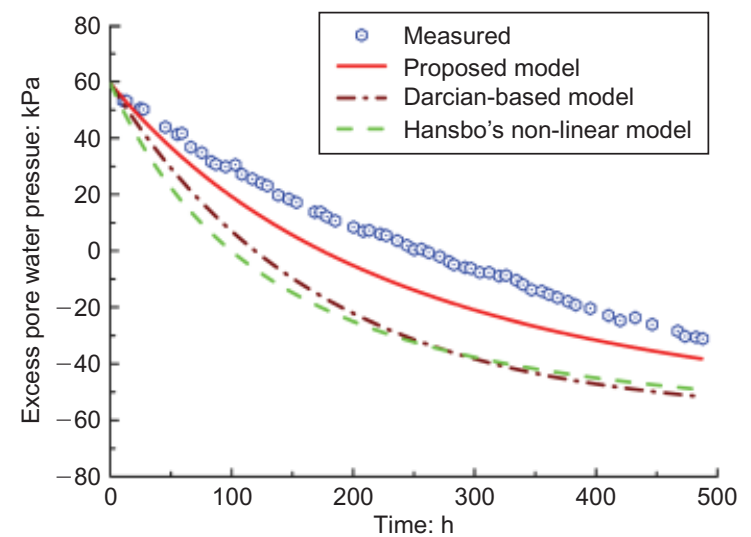

(c)

Fig. 11. (a) Embankment height, (b) settlement and (c) excess pore water pressure for area VC1 at Port of Brisbane. Predictions of existing models based on $c_{\mathrm{h}}=\mathbf{2 \cdot 0} \mathrm{m}^{2} /$ year, back-calculated from best fit of entire settlement curves in areas WD2 and WD4 (approach I)

an analytical model has been developed based on the observed flow relationship to predict the radial consolidation behaviour of soft soil under both surcharge and vacuum preloading. In the proposed model, instead of $c_{\mathrm{h}}, m_{\mathrm{v}}$ is used, and this can readily be determined from the curve of settlement against effective stress. The predictions from the proposed model agree well with the laboratory results based on Rowe cell testing, whereas the predictions of the other models vary with the method adopted for calculating $c_{\mathrm{h}}$. The proposed solution gives a more accurate prediction of the settlement and excess pore water when applied to a selected case history (Port of Brisbane, Australia). In this analysis, the smear effect (due to mandrel-driven prefabricated drains) was included, and the flow relationship was determined based on the measurement in the adjacent areas. For the presented laboratory and field cases a power of 1.3 gives better results than the value of 1.5 recommended by Hansbo (2001). For a given drain pattern, the findings of this study confirm that the flow relationship is a major factor influencing the embankment settlement and excess pore water dissipation. 


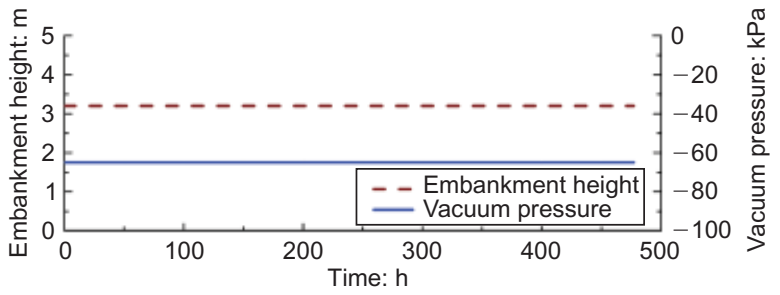

(a)

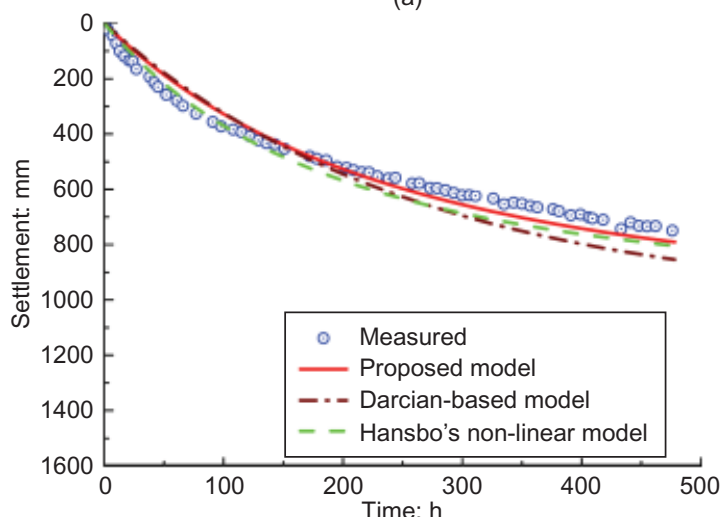

(b)

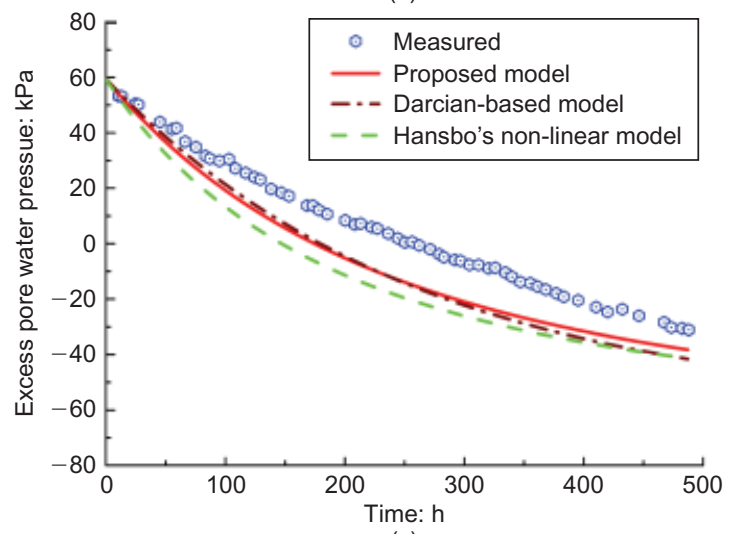

(c)

Fig. 12. (a) Embankment height, (b) settlement and (c) excess pore water pressure for area VC1 at Port of Brisbane. Predictions of existing models based on $c_{\mathrm{h}}=1.3 \mathrm{~m}^{2} /$ year, back-calculated using Asaoka method in areas WD2 and WD4 (approach II)

\section{APPENDIX: ANALYTICAL SOLUTION OF RADIAL} CONSOLIDATION MODEL

The complete solution of the radial consolidation equation (equation (12)) is presented here in detail. To start the solution, equation (12) is represented here again by

$$
\frac{\partial u}{\partial r}=\gamma_{\mathrm{w}}\left(\frac{1}{2 \alpha_{\mathrm{c}}} \frac{\partial \varepsilon}{\partial t}\right)^{1 / \beta}\left(\frac{R^{2}-r^{2}}{r}\right)^{1 / \beta}
$$

Using a binomial series, the last term in the above equation can be expanded to

$$
\begin{aligned}
\left(\frac{R^{2}-r^{2}}{r}\right)^{1 / \beta} & =\left(\frac{R^{2}}{r}-r\right)^{1 / \beta} \\
& =\sum_{i=0}^{\infty}\left[\left(\begin{array}{c}
1 / \beta \\
i
\end{array}\right)(-1)^{i}\left(R^{2}\right)^{(1 / \beta)-i} r^{2 i-(1 / \beta)}\right]
\end{aligned}
$$

where

$$
\left(\begin{array}{c}
1 / \beta \\
i
\end{array}\right)=\frac{1 / \beta[(1 / \beta)-1] \ldots[(1 / \beta)-i+1]}{i !}
$$

is the binomial coefficient.

Substitution of equation (27) into equation (26) gives

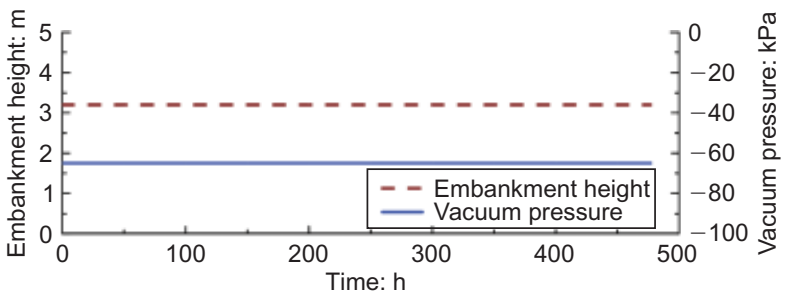

(a)

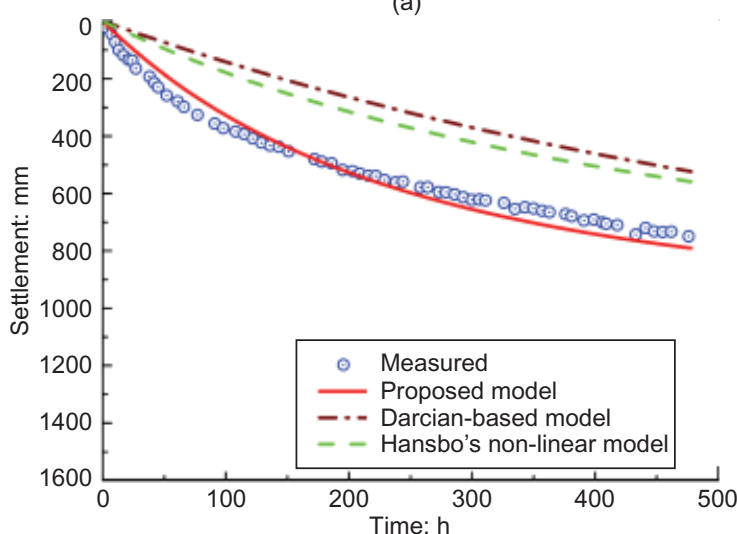

(b)

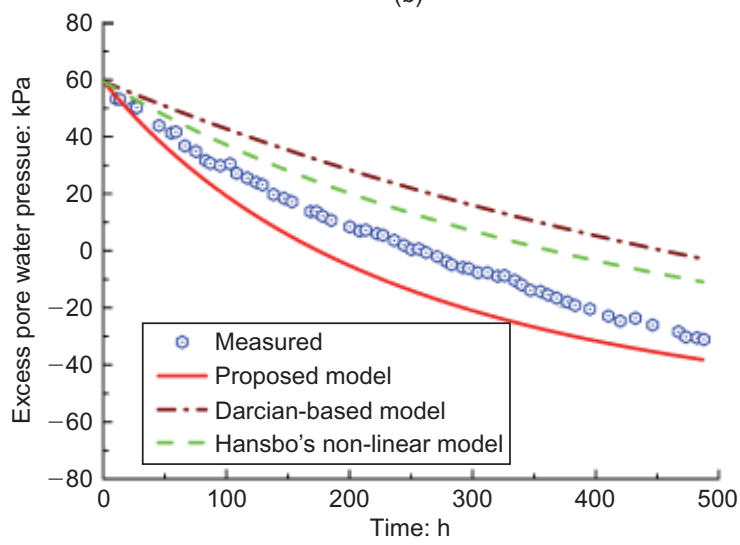

(c)

Fig. 13. (a) Embankment height, (b) settlement and (c) excess pore water pressure for area VC1 at Port of Brisbane. Predictions of existing models based on $c_{\mathrm{h}}=0.5 \mathrm{~m}^{2} /$ year, back-calculated using hyperbolic method in areas WD2 and WD4 (approach III)

$$
\frac{\partial u}{\partial r}=\gamma_{\mathrm{w}}\left(\frac{1}{2 \alpha_{\mathrm{c}}} \frac{\partial \varepsilon}{\partial t}\right)^{1 / \beta} \sum_{i=0}^{\infty}\left[\left(\begin{array}{c}
1 / \beta \\
i
\end{array}\right)(-1)^{i}\left(R^{2}\right)^{(1 / \beta)-i} r^{2 i-(1 / \beta)}\right]
$$

Integrating equation (28) in the $r$ direction with the boundary condition $u=-P_{0}$ at $r=r_{\mathrm{W}}$ yields

$$
u^{\prime}=\eta_{\mathrm{s}} \gamma_{\mathrm{w}}\left(\frac{1}{2 \alpha_{\mathrm{c}}^{\prime}} \frac{\partial \varepsilon}{\partial t}\right)^{1 / \beta}-P_{0}
$$

for $r_{\mathrm{w}} \leqslant r \leqslant r_{\mathrm{s}}$, where

$$
\eta_{\mathrm{s}}=\sum_{i=0}^{\infty}\left[\left(\begin{array}{c}
1 / \beta \\
i
\end{array}\right)\left(\frac{1}{j}\right)(-1)^{i}\left(R^{2}\right)^{(1 / \beta)-i}\left(r^{j}-r_{\mathrm{w}}^{j}\right)\right]
$$

In the above, $u^{\prime}$ is the excess pore water pressure in the smear zone, $P_{0}$ is the magnitude of the vacuum pressure at the drain/soil interface, $r_{\mathrm{s}}$ is the radius of the smear zone, $\alpha_{\mathrm{c}}^{\prime}$ is the substitute for $\alpha_{c}$ in equation (8) for the flow relationship in the smear zone (the flow relationship in the smear zone can be represented by $v=\alpha_{\mathrm{c}}^{\prime} i^{\beta}$ ), and

$$
j=\left(1+2 i-\frac{1}{\beta}\right)
$$

Integrating equation (28) in the $r$ direction outside the smear zone with the boundary condition $u=u^{\prime}$ at $r=r_{\mathrm{s}}$ gives 


$$
u=\eta_{\mathrm{n}} \gamma_{\mathrm{w}}\left(\frac{1}{2 \alpha_{\mathrm{c}}} \frac{\partial \varepsilon}{\partial t}\right)^{1 / \beta}-P_{0}
$$

for $r_{\mathrm{s}} \leqslant r \leqslant R$, where

$$
\eta_{\mathrm{n}}=\sum_{i=0}^{\infty}\left\{\left(\begin{array}{c}
1 / \beta \\
i
\end{array}\right)\left(\frac{1}{j}\right)(-1)^{i}\left(R^{2}\right)^{(1 / \beta)-i}\left[r^{j}+\left(c_{\alpha}-1\right) r_{\mathrm{s}}^{j}-c_{\alpha} r_{\mathrm{w}}^{j}\right]\right\}
$$

and

$$
c_{\alpha}=\left(\frac{\alpha_{\mathrm{c}}}{\alpha_{\mathrm{c}}^{\prime}}\right)^{1 / \beta}
$$

The average excess pore water pressure in the unit cell can then be calculated from

$$
\begin{aligned}
\bar{u} & =\frac{\int_{r_{\mathrm{w}}}^{r_{\mathrm{s}}} 2 \pi r u^{\prime} l \mathrm{~d} r+\int_{r_{\mathrm{s}}}^{R} 2 \pi r u l \mathrm{~d} r}{\pi\left(R^{2}-r_{\mathrm{w}}^{2}\right) l} \\
& =\left(\frac{2}{R^{2}-r_{\mathrm{w}}^{2}}\right)\left(\int_{r_{\mathrm{w}}}^{r_{\mathrm{s}}} r u^{\prime} \mathrm{d} r+\int_{r_{\mathrm{s}}}^{R} r u \mathrm{~d} r\right)
\end{aligned}
$$

Substituting equations (29) and (31) into equation (33) and taking the integrals gives

$$
\bar{u}=\frac{2 n^{2}}{n^{2}-1} \frac{\eta \gamma_{\mathrm{w}}}{R^{2}}\left(\frac{1}{2 \alpha_{\mathrm{c}}} \frac{\partial \varepsilon}{\partial t}\right)^{1 / \beta}-P_{0}
$$

where

$$
\begin{gathered}
\eta=\left(\frac{1}{n}\right)^{3-(1 / \beta)} R^{3+(1 / \beta)} \sum_{i=0}^{\infty}\left\{\left[\left(\begin{array}{c}
1 / \beta \\
i
\end{array}\right)\left(\frac{1}{j n^{2 i}}\right)(-1)^{i}\right]\right. \\
\left.\times\left[\begin{array}{c}
\left(\frac{1}{j}\right)\left[\left(c_{\alpha}-1\right) s^{2+j}+n^{2+j}-c_{\alpha}\right] \\
+\frac{n^{2}-s^{2}}{2}\left(c_{\alpha}-1\right) s^{j}-\frac{n^{2}-1}{2} c_{\alpha}
\end{array}\right]\right\}
\end{gathered}
$$

Then the well-known relationship between the strain rate and excess pore pressure dissipation rate (equation (36)) can be substituted in equation (34), which results in equation (37), representing an alternative expression for $\bar{u}$.

$$
\frac{\partial \varepsilon}{\partial t}=-m_{\mathrm{v}} \frac{\partial \bar{u}}{\partial t}
$$

where $m_{\mathrm{v}}$ is the coefficient of volume compressibility.

$$
\bar{u}=\frac{2 n^{2}}{n^{2}-1} \frac{\eta \gamma_{\mathrm{w}}}{R^{2}}\left(-\frac{m_{\mathrm{v}}}{2 \alpha_{\mathrm{c}}} \frac{\partial \bar{u}}{\partial t}\right)^{1 / \beta}-P_{0}
$$

Rearranging the above equation gives

$$
\frac{\partial \bar{u}}{\partial t}=\left(-\frac{2 \alpha_{\mathrm{c}}}{m_{\mathrm{v}}}\right)\left[\frac{n^{2}-1}{2 n^{2}} \frac{R^{2}}{\eta \gamma_{\mathrm{w}}}\left(\bar{u}+P_{0}\right)\right]^{\beta}
$$

and

$$
\left(\bar{u}+P_{0}\right)^{-\beta} \partial \bar{u}=\left(-\frac{2 \alpha_{\mathrm{c}}}{m_{\mathrm{v}}}\right)\left[\frac{n^{2}-1}{2 n^{2}} \frac{R^{2}}{\eta \gamma_{\mathrm{w}}}\right]^{\beta} \partial t
$$

Integration of equation (39) gives

$$
\begin{aligned}
\bar{u}= & {\left[(1-\beta)\left(-\frac{2 \alpha_{\mathrm{c}}}{m_{\mathrm{v}}}\right)\left(\frac{n^{2}-1}{2 n^{2}} \frac{R^{2}}{\eta \gamma_{\mathrm{w}}}\right)^{\beta} t+\left(\bar{u}_{0}+P_{0}\right)^{1-\beta}\right]^{1 /(1-\beta)} } \\
& -P_{0}
\end{aligned}
$$

$$
\begin{aligned}
\frac{\partial \bar{u}}{\partial t}= & \left(-\frac{2 \alpha_{\mathrm{c}}}{m_{\mathrm{v}}}\right)\left(\frac{n^{2}-1}{2 n^{2}} \frac{R^{2}}{\eta \gamma_{\mathrm{w}}}\right)^{\beta} \\
& \times\left[(1-\beta)\left(-\frac{2 \alpha_{\mathrm{c}}}{m_{\mathrm{v}}}\right)\left(\frac{n^{2}-1}{2 n^{2}} \frac{R^{2}}{\eta \gamma_{\mathrm{w}}}\right)^{\beta} t+\left(\bar{u}_{0}+P_{0}\right)^{1-\beta}\right]^{\beta /(1-\beta)}
\end{aligned}
$$

Substituting equation (41) into equation (36) yields

$$
\begin{aligned}
\frac{\partial \varepsilon}{\partial t}= & 2 \alpha_{\mathrm{c}}\left(\frac{n^{2}-1}{2 n^{2}} \frac{R^{2}}{\eta \gamma_{\mathrm{w}}}\right)^{\beta} \\
& \times\left[(1-\beta)\left(-\frac{2 \alpha_{\mathrm{c}}}{m_{\mathrm{v}}}\right)\left(\frac{n^{2}-1}{2 n^{2}} \frac{R^{2}}{\eta \gamma_{\mathrm{w}}}\right)^{\beta} t+\left(\bar{u}_{0}+P_{0}\right)^{1-\beta}\right]^{\beta /(1-\beta)}
\end{aligned}
$$

Combining equations (29) and (31) with equation (42) leads to equations (43) and (44) for the excess pore water pressures inside and outside the smear zone respectively.

$$
\begin{aligned}
u^{\prime}= & \eta_{\mathrm{s}}\left(\frac{\alpha_{\mathrm{c}}}{\alpha_{\mathrm{c}}^{\prime}}\right)^{1 / \beta}\left(\frac{n^{2}-1}{2 n^{2}} \frac{R^{2}}{\eta}\right) \\
& \times\left[(1-\beta)\left(-\frac{2 \alpha_{\mathrm{c}}}{m_{\mathrm{v}}}\right)\left(\frac{n^{2}-1}{2 n^{2}} \frac{R^{2}}{\eta \gamma_{\mathrm{w}}}\right)^{\beta} t+\left(\bar{u}_{0}+P_{0}\right)^{1-\beta}\right]^{1 /(1-\beta)} \\
& -P_{0}
\end{aligned}
$$

$$
\text { for } \begin{aligned}
r_{\mathrm{w}} \leqslant & r \leqslant r_{\mathrm{s}} \text {; and } \\
u= & \eta_{\mathrm{n}}\left(\frac{n^{2}-1}{2 n^{2}} \frac{R^{2}}{\eta}\right) \\
& \times\left[(1-\beta)\left(-\frac{2 \alpha_{\mathrm{c}}}{m_{\mathrm{v}}}\right)\left(\frac{n^{2}-1}{2 n^{2}} \frac{R^{2}}{\eta \gamma_{\mathrm{w}}}\right)^{\beta} t+\left(\bar{u}_{0}+P_{0}\right)^{1-\beta}\right]^{1 /(1-\beta)} \\
& -P_{0}
\end{aligned}
$$

for $r_{\mathrm{s}} \leqslant r \leqslant R$.

Integrating equation (42) results in the following equation for the axial strain at a given time.

$$
\begin{aligned}
\varepsilon= & -m_{v}\left\{\left[(1-\beta)\left(-\frac{2 \alpha_{\mathrm{c}}}{m_{\mathrm{v}}}\right)\left(\frac{n^{2}-1}{2 n^{2}} \frac{R^{2}}{\eta \gamma_{\mathrm{w}}}\right)^{\beta} t\right.\right. \\
& \left.\left.+\left(\bar{u}_{0}+P_{0}\right)^{1-\beta}\right]^{1 /(1-\beta)}-\left(\bar{u}_{0}+P_{0}\right)\right\}
\end{aligned}
$$

\section{NOTATION}

$c_{\mathrm{c}}$ compression coefficient

$c_{\mathrm{h}}$ coefficient of consolidation in radial direction

$c_{\mathrm{v}}$ coefficient of consolidation in vertical direction

$D_{\mathrm{f}}$ equivalent diameter of influence zone in field

$D_{\mathrm{l}}$ diameter of influence zone in laboratory

$h$ head of water

$i$ hydraulic gradient

$i_{1}$ threshold hydraulic gradient in Hansbo's model

$k$ coefficient of permeability based on linear flow

$k_{\mathrm{h}}$ coefficient of permeability in horizontal direction in undisturbed soil

$k_{\mathrm{h}}^{\prime}$ coefficient of permeability in horizontal direction in smear zone

LL liquid limit

$l$ soil thickness in unit cell

$m$ constant in Hansbo's flow relationship

$m_{\mathrm{v}}$ coefficient of soil volume compressibility 
$n$ ratio of unit cell radius to radius of drain $=R / r_{\mathrm{w}}$

$P_{0} \quad$ magnitude of vacuum pressure at drain/soil interface

PL plastic limit

$Q$ volume of flow

$R$ effective radius, or radius of consolidation cell

$r$ radial distance measure from centre of drain

$r_{\mathrm{A}}, r_{\mathrm{B}}, r_{\mathrm{C}}, r_{\mathrm{D}}$ radial distance from the centre of the sample to regions $\mathrm{A}, \mathrm{B}, \mathrm{C}$ and $\mathrm{D}$ respectively

$r_{\mathrm{BC}}$ radial distance from region $\mathrm{B}$ to region $\mathrm{C}$

$r_{\mathrm{S}}$ radius of smear zone

$r_{\mathrm{W}}$ drain radius

SP surcharge pressure

$s_{\mathrm{u}}$ undrained shear strength

$t$ time

$u$ excess pore water pressure at a given time outside smear zone

$u^{\prime}$ excess pore water pressure at a given time within smear zone

$u_{\mathrm{B}}, u_{\mathrm{C}}$ pore water pressure in regions $\mathrm{B}$ and $\mathrm{C}$ respectively

$\bar{u}$ average excess pore water pressure in unit cell at a given time

$\bar{u}_{0} \quad$ initial average excess pore water pressure in unit cell

VP vacuum pressure

VSR vacuum/total surcharge ratio $=\mathrm{VP} /(\mathrm{SP}+\mathrm{VP})$

$v$ flow velocity

$v_{\mathrm{BC}}$ seepage velocity from region $\mathrm{B}$ to region $\mathrm{C}$

$\alpha_{\mathrm{c}}, \alpha_{\mathrm{c}}^{\prime}$ constants in proposed flow relationship

$\beta$ constant in proposed flow relationship

$\gamma_{\mathrm{w}}$ unit weight of water

$\varepsilon$ axial strain at a given time

$\eta, \eta_{\mathrm{s}}, \eta_{\mathrm{n}}$ coefficients in proposed consolidation model (see Appendix)

$\kappa$ coefficient of permeability based on non-linear flow in Hansbo's model

$\phi^{\prime}$ friction angle

\section{REFERENCES}

Acar, Y. B., Hamidon, A. B., Field, S. D. \& Scott, L. (1985). The effect of organic fluids on hydraulic conductivity of compacted kaolinite. In Hydraulic barriers in soil and rock (eds A. I. Johnson, R. K. Frobel, N. J. Cavalli and C. B. Pettersson), ASTM STP 874, pp. 171-187. West Conshohocken, PA, USA: ASTM International.

Asaoka, A. (1978). Observational procedure of settlement prediction. Soils Found. 18, No. 4, 87-101.

ASTM D422 (2007). Standard test method for particle-size analysis of soils. West Conshohocken, PA, USA: ASTM International.

ASTM D2435 (2004). Standard test methods for one-dimensional consolidation properties of soils using incremental loading. West Conshohocken, PA, USA: ASTM International.

ASTM D4318 (2005). Standard test methods for liquid limit, plastic limit, and plasticity index of soils. West Conshohocken, PA, USA: ASTM International.

ASTM D4767 (2004). Standard test method for consolidated undrained triaxial compression test for cohesive soils. West Conshohocken, PA, USA: ASTM International.

ASTM D6913 (2004). Standard test methods for particle-size distribution (gradation) of soils using sieve analysis. West Conshohocken, PA, USA: ASTM International.

Atkinson, J. H., Richardson, D. \& Robinson, P. J. (1987). Compression and extension of $K_{0}$ normally consolidated kaolin clay. $J$. Geotech. Engng 113, No. 12, 1468-1482.

Barron, R. A. (1948). Consolidation of fine-grained soils by drain wells. Trans. ASCE 113, No. 2346, 718-754.

Carpenter, G. W. \& Stephenson, R. W. (1986). Permeability testing in the triaxial cell. Geotech. Test. J. 9, No. 1, 3-9.

Dubin, B. \& Moulin, G. (1986). Influence of critical gradient on the consolidation of clay. In Consolidation of soils: Testing and evaluation (eds R. N. Yong and F. C. Townsend), ASTM STP 892, pp. 354-377. West Conshohocken, PA, USA: ASTM International.

Edil, T. B. \& Erickson, A. E. (1985). Procedure and equipment factors affecting permeability testing of a bentonite-sand liner material. In Hydraulic barriers in soil and rock (eds A. I.
Johnson, R. K. Frobel, N. J. Cavalli and C. B. Pettersson), ASTM STP 874, pp. 1155-1170. West Conshohocken, PA, USA: ASTM International.

Foreman, D. E. \& Daniel, D. E. (1984). Effects of hydraulic gradient and method of testing on the hydraulic conductivity of compacted clay to water, methanol and heptane. Proc. 10th Ann. Res. Symposium on Land Disposal of Hazardous Waste, Fort Mitchell, KY, 138-144.

Fredlund, M. D., Wilson, G. W. \& Fredlund, D. G. (2002). Use of the grain-size distribution for estimation of the soil-water characteristic curve. Can. Geotech. J. 39, No. 5, 1103-1117.

Gairon, S. \& Swartzendruber, D. (1975). Water flux and electrical potentials in water saturated bentonite. Soil Sci. Soc. Am. Proc. 39, No. 5, 811-817.

Hansbo, S. (1960). Consolidation of clay: With special reference to influence of vertical sand drains, Proceedings of the Swedish Geotechnical Institute, Vol. 18. Stockholm, Sweden: Swedish Geotechnical Institute.

Hansbo, S. (2001). Consolidation equation valid for both Darcian and non-Darcian flow. Géotechnique 51, No. 1, 51-54, http:// dx.doi.org/10.1680/geot.2001.51.1.51

Indraratna, B., Rujikiatkamjorn, C. \& Sathananthan, I. (2005a). Radial consolidation of clay using compressibility indices and varying horizontal permeability. Can. Geotech. J. 42, No. 5, $1330-1341$

Indraratna, B., Sathananthan, I., Rujikiatkamjorn, C. \& Balasubramaniam, A. S. (2005b). Analytical and numerical modeling of soft soil stabilized by prefabricated vertical drains incorporating vacuum preloading. Int. J. Geomech. 5, No. 2, 114-124.

Indraratna, B., Rujikiatkamjorn, C., Ameratunga, J. \& Boyle, P. (2011). Performance and prediction of vacuum combined surcharge consolidation at Port of Brisbane. J. Geotech. Geoenviron. Engng 137, No. 11, 1009-1018.

Kezdi, A. (1958). Cinq ans de mécanique du sol en Hongrie. Ann. Inst. Techn. Bât. et Trav. Publ., No. 127-129, 862-874 (in French)

Kjellman, W. (1952). Consolidation of clayey soils by atmospheric pressure. Proceedings of a conference on soil stabilization, Boston, MA, pp. 258-263.

Kodikara, J. K. \& Rahman, F. (2002). Effects of specimen consolidation on the laboratory hydraulic conductivity measurement. Can. Geotech. J. 39, No. 4, 908-923.

Lutz, J. F. \& Kemper, W. D. (1959). Intrinsic permeability of clay as affected by clay-water interaction. Soil Sci. 88, No. 2, 83-90.

Miller, R. J. \& Low, P. F. (1963). Threshold gradient for water flow in clay systems. Proc. Soil Sci. Soc. Am. 27, No. 6, 605-609.

Mitchell, J. K. \& Younger, J. S. (1967). Abnormalities in hydraulic flow through fine-grained soils. In Permeability and capillarity of soils (ed. A. Johnson), ASTM STP 417, pp. 106-139. West Conshohocken, PA, USA: ASTM International.

Olsen, H. W. (1965). Deviations from Darcy's law in saturated clays. Proc. Soil Sci. Soc. Am. 29, No. 2, 135-140.

Olsen, H. W. (1966). Darcy's law in saturated kaolinite. Water Resour. Res. 2, No. 2, 287-295.

Onoue, A. (1988). Consolidation by vertical drains taking well resistance and smear into consideration. Soils Found. 28, No. 4 $165-174$.

Pane, V., Croce, P., Znidarcic, D., Ho, H. Y., Olsen, H. W. \& Schiffman, R. L. (1983). Effects of consolidation on permeability measurements for soft clay. Géotechnique 33, No. 1, 67-72, http://dx.doi.org/10.1680/geot.1983.33.1.67.

Robinson, R. G. (2009). Analysis of radial consolidation test data using log-log method. Geotech. Test. J. 32, No. 2, 1-7.

Sathananthan, I. \& Indraratna, B. (2006). Plane-strain lateral consolidation with non-Darcian flow. Can. Geotech. J. 43, No. 2 119-133.

Schiffman, R. L. (1958). Consolidation of soil under time-dependent loading and varying permeability. Proc. Highway Research Board 37, 584-617.

Schmid, W. E. (1957). The permeability of soils and the concept of a stationary boundary layer. Proc. ASTM 57, 1195-1218.

Sridharan, A., Prakash, K. \& Asha, S. R. (1996). Consolidation behaviour of clayey soils under radial drainage. Geotech. Test. J. 19, No. 4, 421-431.

Tan, T. S., Inoue, T. \& Lee, S. L. (1991). Hyperbolic method for consolidation analysis. J. Geotech. Engng 117, No. 11, 1723-1736. 
Terzaghi, K. (1925). Erdbaumechanik auf bodenphysikalisher grundlage. Leipzig, Germany: Franz Deuticke (in German).

Vinod, J. S., Sridharan, A. \& Indraratna, B. (2010). Determination of coefficient of radial consolidation using steepest tangent method. Geotech. Geol. Engng 28, No. 4, 533-536.

Winterkorn, H. F. (1954). Water movement through porous hydrophilic systems under capillary, electrical, and thermal potentials. Symposium on permeability of soils, Chicago, IL, ASTM STP $163,27-35$.
Yoshikuni, H. \& Nakanodo, H. (1974). Consolidation of finegrained soils by drain wells with finite permeability. Soils Found. 14, No. 2, 35-46.

Zeng, G. X. \& Xie, K. H. (1989). New development of the vertical drain theories. Proc. 12th Int. Conf. Soil Mech. Found. Engng, Rio de Janeiro 2, 1435-1438.

Zou, Y. (1996). A non-linear permeability relation depending on the activation energy of pore liquid. Géotechnique 46, No. 4, 769-774, http://dx.doi.org/10.1680/geot.1996.46.4.769. 